OPEN ACCESS

Edited by:

Samuel Abiven,

University of Zurich, Switzerland

Reviewed by:

Caroline Margaret Preston, Natural Resources Canada, Canada

Philippa Louise Ascough,

Scottish Universities Environmental Research Centre, United Kingdom

*Correspondence:

Rebecca B. Abney rebabney@iu.edu

Specialty section: This article was submitted to Biogeoscience,

a section of the journal

Frontiers in Earth Science

Received: 16 September 2017 Accepted: 13 November 2017

Published: 29 November 2017

Citation:

Abney RB, Sanderman J, Johnson D

Fogel ML and Berhe AA (2017)

Post-wildfire Erosion in Mountainous

Terrain Leads to Rapid and Major Redistribution of Soil Organic Carbon. Front. Earth Sci. 5:99.

doi: 10.3389/feart.2017.00099

\section{Post-wildfire Erosion in Mountainous Terrain Leads to Rapid and Major Redistribution of Soil Organic Carbon}

\author{
Rebecca B. Abney ${ }^{1,2 *}$, Jonathan Sanderman ${ }^{3,4}$, Dale Johnson ${ }^{5}$, Marilyn L. Fogel ${ }^{6}$ and \\ Asmeret Asefaw Berhe ${ }^{1}$ \\ ${ }^{1}$ Environmental Systems, Life and Environmental Sciences, University of California, Merced, Merced, CA, United States, \\ ${ }^{2}$ School of Public and Environmental Affairs, Indiana University, Bloomington, IN, United States, ${ }^{3}$ Woods Hole Research \\ Center, Falmouth, MA, United States, ${ }^{4}$ Commonwealth Scientific and Industrial Research Organisation, Hobart, TAS, \\ Australia, ${ }^{5}$ Department of Natural Resources and Environmental Science, University of Nevada, Reno, NV, United States, \\ ${ }^{6}$ Department of Earth Sciences, University of California, Riverside, Riverside, CA, United States
}

Catchments impacted by wildfire typically experience elevated rates of post-fire erosion and formation and deposition of pyrogenic carbon (PyC). To better understand the role of erosion in post-fire soil carbon dynamics, we determined distribution of soil organic carbon (SOC) in different chemical fractions before and after the Gondola fire in South Lake Tahoe, CA. We analyzed soil samples from eroding and depositional landform positions in control and burned plots pre- and post-wildfire (in 2002, 2003, and 10-years post-fire in 2013). We determined elemental concentrations, stable isotope compositions, and biochemical composition of organic matter (OM) using mid-infrared (MIR) spectroscopy for all of the samples. A subset of samples was analyzed by ${ }^{13} \mathrm{C}$ cross polarization magic angle spinning nuclear magnetic resonance spectroscopy (CPMAS ${ }^{13} \mathrm{C}-\mathrm{NMR}$ ). We combined the MIR and CPMAS ${ }^{13} \mathrm{C}-\mathrm{NMR}$ data in the Soil Carbon Research Program (SCaRP) partial least squares regression model to predict distribution of soil carbon into three different fractions: (1) particulate, humic, and resistant $O M$ fractions representing relatively fresh larger pieces of $\mathrm{OM}$, (2) fine, decomposed $\mathrm{OM}$, and (3) pyrogenic C, respectively. Samples from the post-fire eroding landform position showed no major difference in SOC fractions 1 year post-fire. The depositional samples, however, had increased concentrations of all SOC fractions, particularly the fraction that resembles PyC, 1 year post-fire (2002), which had a mean of $160 \mathrm{~g} / \mathrm{kg}$ compared with burned hillslope soils, which had $84 \mathrm{~g} / \mathrm{kg}$. The increase in all SOC fractions in the post-fire depositional landform position 1 year post-fire indicates significant lateral mobilization of the eroded PyC. In addition, our NMR analyses revealed a post-fire increase in both the aryl and O-aryl carbon compounds in the soils from the depositional landform position, indicating increases in soil PyC concentrations post-fire. After 10 years, the $\mathrm{C}$ concentration from all three fractions declined in the depositional landform position to below pre-fire levels likely due to further erosion or elevated rates of decomposition. Thus, we found, at this site, that both fire and erosion exert significant influence on the distribution of PyC throughout a landscape and its long-term fate in the soil system.

Keywords: erosion, pyrogenic carbon, soil organic carbon, stabilization, wildfire 


\section{INTRODUCTION}

The soil system plays major role in the global terrestrial carbon (C) cycle, as it stores more $\mathrm{C}$ than the biosphere and atmosphere combined (Post and Kwon, 2000; Lal, 2003a; Scharlemann et al., 2014) in pools that cycle at a slower rate than the $C$ in the atmosphere or biosphere (Lal, 2004). The ability of the soil system to store and cycle carbon, however, is modified by a range of physical perturbations that the soil system experiences, including fire and erosion (Lal, 2003b; Berhe et al., 2007; Bird et al., 2015; Santin et al., 2015).

Fire can have multiple direct and indirect effects on the biogeochemical cycling of $\mathrm{C}$ in the terrestrial ecosystem. For example, the release of nutrients from burned biomass can lead to a spike in initial productivity and subsequent regrowth in plant life post-fire (Johnson et al., 2004, 2007). The loss of vegetation that would otherwise stabilize soil in eroding landform positions, along with increased soil hydrophobicity after moderate severity fires leaves soil more directly exposed to weathering and erosion (DeBano, 2000; Shakesby et al., 2000; Larsen et al., 2009). Fires can also raise soil $\mathrm{pH}$, alter cation exchange capacity, and change the soil organic matter (SOM) composition (Giovannini et al., 1988; DeBano, 1991; Certini, 2005; Liang et al., 2006; Araya et al., 2016).

Fire leads to the formation and deposition of pyrogenic carbon (PyC) on topsoil. Broadly, $\mathrm{PyC}$ is $\mathrm{C}$ that has been chemically altered by fire, and includes a spectrum of materials ranging from charred biomass to soot and ash (Masiello, 2004; Bird et al., 2015). Generally, PyC is considered to have a longer mean residence time than non-pyrogenic soil $\mathrm{C}$, typically on the multi-centennial time scale (Hammes et al., 2008; Bird et al., 2015). However, in the past two decades, there has been growing evidence for $\mathrm{PyC}$ decomposing on shorter time scales, on the order of days to years (Cheng et al., 2006; Nguyen et al., 2009; Soucémarianadin et al., 2015). Furthermore, Bird et al. (2015) suggested a multi-pool model of PyC decomposition, where physical or chemical components of $\mathrm{PyC}$ are considerably more susceptible to decomposition than others. Ultimately, the breakdown of $\mathrm{PyC}$ and its loss from the soil system appear to be controlled by environmental conditions, particularly temperature and moisture, in addition to soil-specific conditions, such as landform position, aggregation, and depth, among others (Bird et al., 2015; Boot et al., 2015). Current estimates of PyC mean residence time in soil range from 250 to 300 years (Hammes et al., 2008), but the lack of data or predictive capability for the time scales and magnitude of PyC erosion post-fire potentially adds considerable uncertainty to these estimates (Bird et al., 2015).

Soil erosion laterally transports 1-5 Gt C per year (Stallard, 1998; Battin et al., 2009). The amount of material mobilized in a particular watershed is dependent on the intensity and duration of rainfall, groundcover, vegetation, slope gradient, and recent fire history (Renard et al., 1997; Pierson et al., 2009). Between 70 and $90 \%$ of the soil and associated carbon mobilized from eroding landscapes is deposited within the source or adjacent watersheds (Gregorich et al., 1998; Stallard, 1998). Local deposition of eroded material, along with dynamic replacement of eroded $\mathrm{C}$ by production of new photosynthate and stabilization of at least some of the eroded $\mathrm{C}$ in the depositional settings, leads to an erosion induced terrestrial sink for atmospheric $\mathrm{CO}_{2}$ (Harden et al., 1999; Berhe et al., 2007).

Fire and erosion interact to modify a range of soil physical and chemical properties post-fire. The loss of vegetation after high severity fires is one of the main drivers of post-fire erosion, as vegetation plays a major role in stabilizing eroding soils (Shakesby et al., 1993; Larsen et al., 2009; Pierson et al., 2009). In extreme cases, this loss of vegetation can lead to debris and ash flows when intense rainfall events occur on recently burned hillslopes (Carroll et al., 2007). In addition to the loss of stabilizing vegetation, fire can produce a hydrophobic layer below the surface of the soil which can change the hydrologic flow along a hillslope (DeBano, 1991; Shakesby et al., 2000), reducing rate of water infiltration to soil and enhancing rates of runoff (DeBano, 1991; Shakesby et al., 2000; Pierson et al., 2013).

Post-fire erosion of topsoil rich in PyC can play an important role in controlling the stock and residence times of $\mathrm{PyC}$ in the soil system. So far, relatively few studies have focused specifically on the erosion of PyC. From the available data, it is becoming increasingly clear that $\mathrm{PyC}$ is highly susceptible to erosive forces, more so than non-pyrogenic C (Rumpel et al., 2006; Yao et al., 2014). After high severity wildfires, PyC has been documented to have enrichment ratios (concentration in eroded sediment divided by concentration in source soils) of up to 2.3 across the watershed scale (Rumpel et al., 2006). The observed high enrichment ratios of $\mathrm{PyC}$ are partly due to its relatively lower density compared with other SOM constituents, along with its concentration in the upper soil horizons and hydrophobicity (DeBano, 2000; Rumpel et al., 2006, 2015; Brewer et al., 2014). There is some evidence that erosion of $\mathrm{PyC}$ is controlled by different processes than non-pyrogenic C. Yao et al. (2014) found that the proportion of $\mathrm{PyC}$ compared with total $\mathrm{C}$ decreases with increasing soil erosion, while total $\mathrm{C}$ erosion increases with bulk soil erosion due to mobilization of deep and mineral-associated C. Erosional loss of PyC from sloping landform positions and depositional input of $\mathrm{PyC}$ into lower-lying depositional landform positions post-fire can significantly decrease or increase its mean residence time, as is observed with bulk $\mathrm{C}$ in soils that are not fire impacted (Berhe et al., 2007, 2012). Furthermore, the previous research on non-pyrogenic $\mathrm{C}$ has indicated that the burial of eroded $\mathrm{C}$ in lower lying depositional landform positions can lead to stabilization of through physical and chemical mechanisms (Berhe et al., 2007). It is likely that, in a similar manner, burial of eroded PyC can increase its mean residence time for up to millennia (Marin-Spiotta et al., 2014; Bird et al., 2015).

Vertical mobilization of $\mathrm{PyC}$ and other SOM within a soil profile occurs mainly due to leaching, bioturbation, and illuviation (Eckmeier et al., 2007; Rumpel et al., 2015). Leaching is primarily responsible for vertical transport of dissolved constituents, while bioturbation and illuviation, or the downwards transport of particles via water flow, can move particulate $\mathrm{PyC}$ and $\mathrm{OM}$ down the soil profile. In post-fire environments, the rate of vertical mobilization of $\mathrm{PyC}$ depends on the size and solubility of the $\mathrm{PyC}$, the nature of the porous media, including soil texture, bulk density, and porosity, and the 
rate of water flow through soil, which is driven by rainfall amount and intensity (Bird et al., 2015). Literature reported values for vertical mobilization of freshly applied PyC are typically on the order of mm per year (Major et al., 2010; Rumpel et al., 2015), although this may differ after natural wildfires and with aged char. The degradation of $\mathrm{PyC}$, and release into the dissolved phase, creates a slow, centennial-scale loss of PyC from the soil. As $\mathrm{PyC}$ is exposed to environmental conditions, it degrades and becomes more soluble and can be mobilized at rates more than 40-55 times that from fresh char (Abiven et al., 2011).

The main objective of this study is to understand how PyC is mobilized laterally and vertically within soil profiles post-fire and to understand how mobilization of $\mathrm{PyC}$ impacts its longterm persistence in soil. To accomplish these objectives, we used a combination of spectroscopic techniques to determine how postfire erosion changes distribution of $\mathrm{C}$ and soil organic carbon (SOC) fractions at eroding and depositional landform positions at the site of the Gondola Fire, South Lake Tahoe, California. Specifically, we determine: (a) how stocks of PyC and other SOC fractions in eroding and depositional landform positions change after fire; (b) how lateral distribution of material controls stocks of PyC and SOC fractions over short (1 year) and longer (10 year) timescales; and (c) the rates of vertical mobilization of $\mathrm{PyC}$ and $\mathrm{C}$ in other fractions down the soil profile post-fire.

\section{METHODS}

\section{Site Description}

The Gondola Fire burned over 270 ha on July 3, 2002, on the south shore of Lake Tahoe $\left(38^{\circ} 57^{\prime} \mathrm{N} ; 119^{\circ} 55^{\prime} \mathrm{W}\right.$, Figure 1), near Stateline, NV (Saito et al., 2007). The Gondola fire was characterized as a moderate severity burn, with partial consumption of the $\mathrm{O}$ horizon, and significant heat transfer down to $1 \mathrm{~cm}$ of mineral soil, where temperatures reached up to $200^{\circ} \mathrm{C}$ (Carroll et al., 2007). The loss of vegetation during the Gondola Fire lead to a loss of $20 \mathrm{Mg} / \mathrm{ha}$ of $\mathrm{C}$ and $257 \mathrm{~kg} / \mathrm{ha}$ from the ecosystem (Johnson et al., 2007). Two weeks after the fire, on
July 18, an intense precipitation event that deposited $15.2 \mathrm{~mm}$ of precipitation as rain and hail mobilized $380 \mathrm{Mg}$ (metric tons) of material downslope, which was deposited in a downslope riparian area that borders the Edgewood Creek (Figure 2). The depositional area was about 0.8 ha in size and was densely vegetated with slopes of 0 to 5\% (Carroll et al., 2007; Saito et al., 2007).

The study area is characterized by Mediterranean climate with cold and snowy winters and warm to hot summers. The site receives most of its $87 \mathrm{~cm}$ of mean annual precipitation as snow and has a mean annual temperature of $6.7^{\circ} \mathrm{C}$. The study area is underlain by granitic parent material and is a part of the Cagwin-Rock Outcrop. Soils of the study area are classified as coarse, loamy sand, mixed Typic Cryopsamments (Carroll et al., 2007; Johnson et al., 2007). The dominant vegetation in the area includes white fir (Abies concolor), Jeffery pine (Pinus jeffreyi), and Sugar pine (Pinus lambertianna) in the overstory; and Sierra chinquapin (Castanopsis sempervirens), currant (Ribes spp.), snowbrush (Ceanothus velutinis), and bitter brush (Purshia tridentata) in the understory (Saito et al., 2007).

\section{Sampling Design}

This site had 16 previously established hillslope sampling plots (Figure 1), in which seven were burned during the fire, seven were unburned, and two were partially burned (Carroll et al., 2007). Directly below the burned hillslope, within the identified deposition area of eroded material from the hillslope plots, 17 sites were selected to represent the variability within the previously identified area where the eroded material from the ash flow was initially deposited (Carroll et al., 2007). These plots were sampled before the Gondola Fire, in late spring in 2002. The same plots were resampled 1-year post-fire, during the summer of 2003, and then 10-years post-fire in the summer of 2013, with the addition of 13 new sites in the depositional area. These additional sites were selected to better capture the variability in soil properties from this landform position, and since the previous $\mathrm{C}$ and $\mathrm{N}$ data from these sites were highly variable, likely resulting from the multitude of sources for material deposited
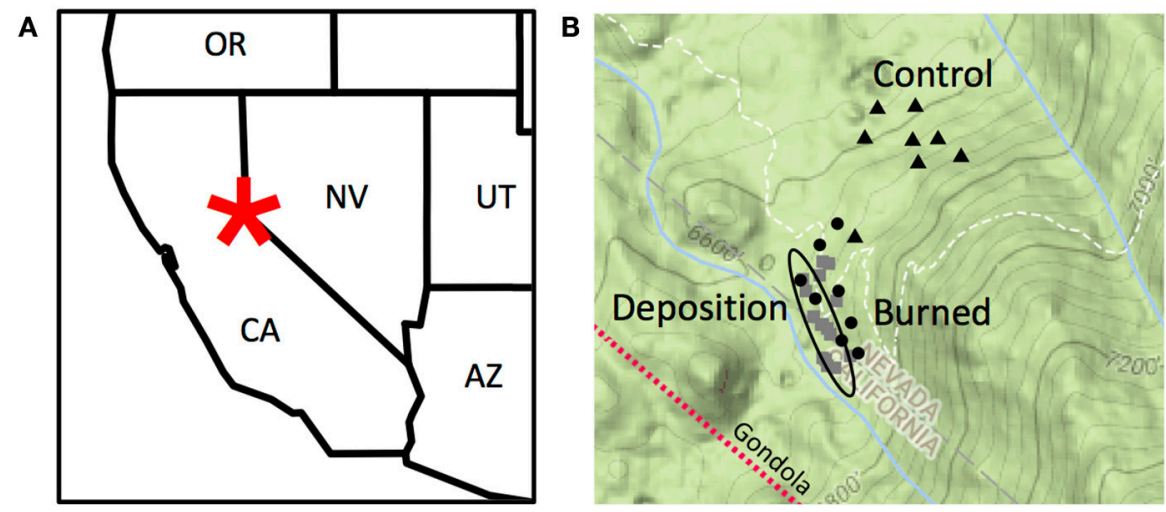

FIGURE 1 | The Gondola Fire occurred outside Stateline, Nevada, in the Van Sickle Bi-State Park (A). Burned plots are indicated by circles; unburned, control plots are indicated by triangles; and selected depositional sites that were analyzed via nuclear magnetic resonance spectroscopy are indicated by squares and are encircled (B) in this topography map (B). The topography map (B) is copyright Google Maps 2017. 
A

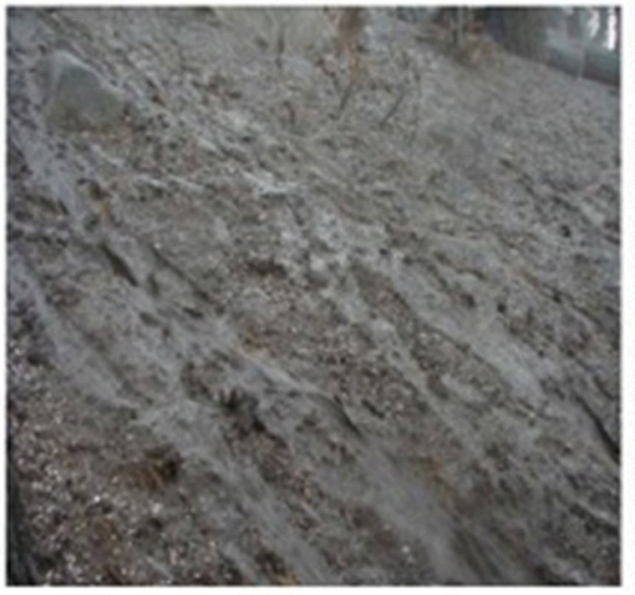

B

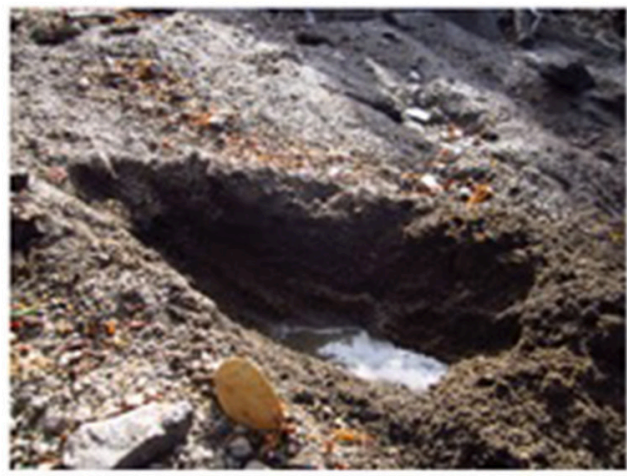

C

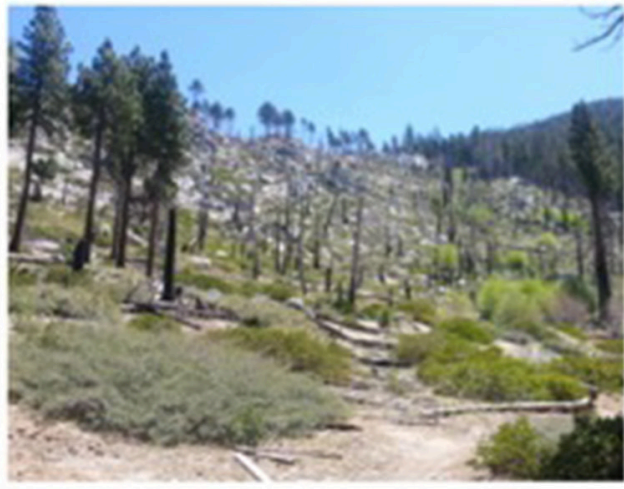

FIGURE 2 | A major ash flow occurred after the fire in 2002 (A, photo by J. Howard). The hydrophobic layer (B, photo R. Abney) created during the fire persists through the recent sampling (photo from November 2012, R. Abney) No canopy is left in portions of this moderate severity fire (C, May 2013, R. Abney).

in this location. In the eroding hillslope plots, soil samples were collected from five random locations within each plot by depths of $0-10,10-30,30-60$, and $60-100 \mathrm{~cm}$, which approximately corresponds to genetic horizons A11, A12, AC, and C (Johnson et al., 2007). In the depositional sites, soil was collected from the depth of $0-15 \mathrm{~cm}$, to capture the mainly ash material that was initially deposited in that landform position, although the profile at this landform position extended deeper. The five replicates from the hillslope soils were composited and homogenized, and all samples were passed through a $2-\mathrm{mm}$ sieve prior to further laboratory analysis. The 2002 and 2003 samples were previously analyzed for various soil and elemental properties, and section Basic Soil, Elemental, and Isotopic Analyses describes the analysis of samples collected in 2013, which duplicates the analyses conducted on the 2003 and 2003 samples, except for the addition of stable isotope analyses.

\section{Basic Soil, Elemental, and Isotopic Analyses}

Air-dried, sieved soils were analyzed for $\mathrm{pH}$ in a 1:2 ratio of soil to both water and $0.01 \mathrm{M} \mathrm{CaCl}_{2}$ solutions with a Fisher Scientific Basic Probe (AB15 meter, Waltham, MA). Gravimetric water content was measured via drying approximately $10 \mathrm{~g}$ subsets of field-moist soil in an oven at $105^{\circ} \mathrm{C}$ for $48 \mathrm{~h}$. Bulk density was determined by the core method, where a $5 \times 10 \mathrm{~cm}$ core was hammered into the soil, and dried at $105^{\circ} \mathrm{C}$ for $48 \mathrm{~h}$.

Prior to $\mathrm{C}$ and $\mathrm{N}$ elemental and isotopic analysis, air-dried soils were ground for $3 \mathrm{~min}$ in a ball mill $(8,000 \mathrm{M}$ Spex Mill, SPEX Sample Prep, Metuchen, NJ) to a homogenous fine powder. Samples were tested for carbonates by reacting them with $1 \mathrm{M}$ $\mathrm{HCl}$. No effervescence was observed, so we concluded that these samples had no carbonates and hence the total organic carbon concentration in the soils is equal to total carbon concentration. For $\mathrm{C}, \mathrm{N}$, and stable isotopic analyses for $\delta^{13} \mathrm{C}$ and $\delta^{15} \mathrm{~N}$, we weighed between 15 and $40 \mathrm{mg}$ of ground soil into tin capsules. These samples were combusted in a Costech ECS 4010 CHNSO Environmental Analyzer (Valencia, CA) connected via a Conflo IV interface (Thermo Finnegan, San Jose, CA) to a Delta V Plus Isotope Ratio mass spectrometer (ThermoFisher Scientific, Waltham MA). All C and N concentration values are reported as oven-dry sample weight. The stable isotope values are reported using the $\delta$ notation, in units of per mil (\%o). Samples were measured against peach leaf and acetanilide, with standard errors of $\pm 0.23 \delta^{15} \mathrm{~N}$ and $\pm 0.09 \delta^{13} \mathrm{C}$ variation for peach leaf and \pm $0.15 \delta^{15} \mathrm{~N}$ and $\pm 0.07 \delta^{13} \mathrm{C}$ variation for acetanilide. Duplicate samples had standard errors of $\pm 0.20 \delta^{15} \mathrm{~N}$ and $\pm 0.05 \delta^{13} \mathrm{C}$. The higher variation in standards compared with samples is likely due to them spanning numerous sample runs and due to variations in the size of the standards across different sample runs. Our results were calibrated relative to international standards (e.g., NBS-22, $\mathrm{N}-1$, and N-2) and are referenced relative to atmospheric $\mathrm{N}_{2}$ and Vienna Pee Dee Belemnite (VPDB).

\section{Spectroscopy}

Bulk chemical characterization and determination of $\mathrm{PyC}$ concentrations in the samples were carried out by combining ${ }^{13}$ C-CPMAS-Nuclear Magnetic Resonance (NMR) and MidInfrared (MIR) Spectroscopy. The data derived from ${ }^{13} \mathrm{C}$ NMR and MIR along with partial least squares regression analysis (MIR/PLSR) was then used to determine the proportion of PyC in the soil samples. This NMR and MIR/PLSR technique reliably estimates the concentration of $\mathrm{PyC}$ across a range of soil types and concentrations of bulk C and PyC (Skjemstad et al., 2004; Janik et al., 2007; Baldock et al., 2013a) and is also the most cost 
and time-effective technique for quantifying the amount of $\mathrm{PyC}$ in soil to date.

Mid-Infrared spectroscopy (MIR) analysis was conducted on all ground soils on a Thermo Nicolet 6700 spectrometer (ThermoFisher Scientific, Waltham, MA) using a Pike AutoDiff diffuse reflectance attachment (Pike Technologies, Madison, WI), as described in Sanderman et al. (2011). A KBr beam-splitter scanned the samples 60 times and produced absorbance spectra from wavenumbers $7,800-400 \mathrm{~cm}^{-1}$. Spectra were background corrected against silicon carbide and then baseline corrected. Peak region assignments were adapted from Araya et al. (2017).

A subset of samples was analyzed via ${ }^{13} \mathrm{C}$-CPMAS NMR spectroscopy on a Bruker Avance system (200 MHz) equipped with a $4.7 \mathrm{~T}$ wide-bore magnet with a resonance frequency of $50.33 \mathrm{MHz}$. The Kennard-Stone algorithm was utilized to pick 20 samples for NMR analysis that incorporated the most variability in the MIR dataset (Kennard and Stone, 1969). This algorithm and principal components analysis demonstrated that most variability was in the deposition samples, and first axis accounted for $86 \%$ of the variance in the MIR data. The NMR analyses were conducted on only depositional landform position soils, as the eroding soils did not produce usable spectra, likely due to either the low $\mathrm{C}$ observability of these samples or paramagnetic interference. Principal component analysis of the MIR spectra confirmed that most of the variability in the soil chemical properties was in the depositional soil samples. Samples for NMR analysis were packed into a $7 \mathrm{~mm}$ zirconia rotor, and a standard cross polarization experiment was performed using a pulse of $3.2 \mu \mathrm{s}, 195 \mathrm{~W}, 90^{\circ}$, a contact time of $1 \mathrm{~ms}$ and a recycle delay of $1 \mathrm{~s}$ (Sanderman et al., 2011; Baldock et al., 2013a).

Of the 20 samples selected for NMR, nine of them produced poor quality spectra and were demineralized with HF prior to re-analysis to increase $\mathrm{C}$ content of samples, decrease noise in the spectra, and remove interference from paramagnetic species in soil (Smernik and Oades, 2002). This method can alter SOM composition (Sanderman et al., 2017), but has been widely used to make spectra collection possible (Schmidt et al., 1997). To demineralize the samples, they were washed nine times with $45 \mathrm{~mL}$ of $2 \% \mathrm{HF}$ over the course of a week, and then three times with DI water (Skjemstad, 1994; Sanderman et al., 2011). To determine $C$ observability, glycine was used as an external reference (Smernik and Oades, 2000a,b), and from the NMR analysis, 18 usable spectra were produced, with C observability over $25 \%$. Spectra were compared to a glycine standard for observability. For these NMR analyses, 10-20,000 scans were collected per sample, and the collected spectra were integrated into eight regions: $0-45 \mathrm{ppm}$ (Alkyl), 45-60 ppm (N-Alkyl/Methoxyl), 60-95 ppm (O-Alkyl), 95-110 ppm (Di-OAlkyl), 110-145 ppm (Aryl), 145-165 ppm (O-Aryl), 165-190 ppm (Amide/Carboxyl), and 190-215 ppm (Ketone).

For the samples from erosional sites, the Soil Carbon Research Program (SCaRP) MIR-PLSR model was used to predict three organic C fractions within the soil samples: resistant organic carbon (ROC, particles that are chemically similar to charcoal, or PyC), particulate organic carbon (POC, particles 50-2,000 $\mu \mathrm{m}$ excluding $\mathrm{PyC}$ ), and humic organic carbon (HOC, particles $<50 \mu \mathrm{m}$ excluding PyC) (Baldock et al., 2014). This model has proven to be a reliable and time-effective method for predicting soil fractions and has been demonstrated a reasonable predictor across different land uses and vegetation types in and out of Australia (Baldock et al., 2013b; Ahmed et al., 2017; Jauss et al., 2017). The SCaRP model is based on 312 soils collected from agricultural soils across Australia, and it independently predicts organic carbon originating from three fractions without the need for mechanical processing of samples (Baldock et al., 2013a). Due to the independent predictions of the three fractions within this model, the sum of $\mathrm{C}$ in each fraction does not necessarily add up to $100 \%$, and the error of the total C predictions averaged $108 \pm$ $11 \%$ of the measured total $\mathrm{C}$ concentration.

However, due to a poor fit of the SCaRP model to the PyC fraction in the depositional soils, a separate NMR/MIR PLSR was created from the NMR and MIR data collected on these samples using the partitioning of $\mathrm{OC}$ into $\mathrm{PyC}$ and non-PyC components using the NMR data as described by Baldock et al. (2013a). This separate, 6-factor model built on square root of transformed PyC data $(n=18)$ explained $87 \%$ of the variance using leave-one-out cross validation with a relative root mean square error of $17 \%$.

\section{Data Analysis}

All data analyses and figure generation for this observational study were conducted in RStudio (version 1.0.316, rstudio.com). Separate linear mixed effects models were built to (1) assess the transport of organic carbon fractions and bulk carbon through the soil profile with time, and (2) to assess surficial transport of these fractions across the surface of the landscape $(0-10 \mathrm{~cm}$ for eroding hillslope and $0-15 \mathrm{~cm}$ for depositional soil). The depth model (1) predicted SOC fraction using time, depth, and burning as fixed factors and plot number as a random factor. The surface transport model (2) predicted SOC fraction used time, landform position, and burning as fixed factors and plot as a random factor. Models were tested for significance $(p<0.05)$ by comparing null intercept-only models to models with fixed and random effects using the likelihood test. Differences between treatments were assessed using a Tukey Honest Significant Difference test and were also assumed significant at $p<0.05$. For all other statistical comparisons without time as a factor, two-way ANOVAs were used with depth and burn or control as predictors. Means are presented with standard error with $n=8$ for eroding hillslope samples and $n=30$ for depositional samples.

\section{RESULTS}

\section{Bulk Soil Properties and Elemental Concentrations}

Soils from the eroding landform positions were generally acidic pre-fire across all sampling times. However, at depths below 30 $\mathrm{cm}$ in 10-year post-fire sampling period the soil $\mathrm{pH}$ values were in the neutral range (Table 1). The $\mathrm{pH}$ of the eroding soils, in both the burn and control plots, increased after the fires by up to 1.25 units. Bulk density showed $<0.2 \mathrm{~g} / \mathrm{cm}^{3}$ change in the 1 year postfire time point, with the values increasing in the burned plots and decreasing in control plots. Soils at the depositional landform 
position had a $\mathrm{pH}$ range and bulk density values that were similar to the topsoil from the eroding position.

Soils from the eroding positions had $<20 \mathrm{~g} / \mathrm{kg} \mathrm{C}$, in which C concentrations showed a consistent, but statistically not significant $(p=0.83)$, decreasing trend with depth in both the burn and control plots in the control and burn plots (Figure 3). The soils generally had very low $\mathrm{N}$ concentrations $(<0.01 \mathrm{~g} / \mathrm{kg})$. There was a marked decrease in concentration of both $\mathrm{C}$ and
$\mathrm{N}$ in topsoil $(0-10 \mathrm{~cm})$ immediately post-fire, but the values reverted to pre-fire levels at the 10 -year post-fire sampling period (Figure 3).

In contrast to the eroding soils, the total $\mathrm{C}$ concentrations in depositional soils ranged from 20 to $100 \mathrm{~g} / \mathrm{kg}$, and increased significantly between the pre-fire and post-fire time points ( $p=0.00$, Figure 4). The depositional soils did not significantly $(p=0.38)$ differ in $\mathrm{N}$ concentration than those from the eroding

TABLE 1 | Soil pH and bulk density for the eroding landform position.

\begin{tabular}{|c|c|c|c|c|c|c|c|c|c|}
\hline \multirow[t]{2}{*}{ Location } & \multirow[t]{2}{*}{ Depth } & \multicolumn{3}{|c|}{ Pre-fire } & \multicolumn{2}{|c|}{ Post-fire } & \multicolumn{3}{|c|}{ Ten-years post-fire } \\
\hline & & $\mathrm{pH}$ in $\mathrm{H}_{2} \mathrm{O}$ & $\mathrm{pH}$ in $\mathrm{CaCl}_{2}$ & $\begin{array}{l}\text { Bulk density } \\
\left(\mathrm{g} / \mathrm{cm}^{3}\right)\end{array}$ & $\mathrm{pH}$ in $\mathrm{H}_{2} \mathrm{O}$ & $\mathrm{pH}$ in $\mathrm{CaCl}_{2}$ & $\mathrm{pH}$ in $\mathrm{H}_{2} \mathrm{O}$ & $\mathrm{pH}$ in $\mathrm{CaCl}_{2}$ & $\begin{array}{c}\text { Bulk density } \\
\left(\mathrm{g} / \mathrm{cm}^{3}\right)\end{array}$ \\
\hline \multirow[t]{4}{*}{ Eroding (burned) } & $0-10 \mathrm{~cm}$ & $5.82(0.11)$ & $5.09(0.11)$ & $1.24(0.07)$ & $6.69(0.11)$ & $5.98(0.20)$ & $6.54(0.13)$ & $5.57(0.11)$ & $1.41(0.05)$ \\
\hline & $10-30 \mathrm{~cm}$ & $5.77(0.10)$ & $4.98(0.08)$ & - & $6.37(0.23)$ & $5.74(0.29)$ & $6.64(0.10)$ & $5.68(0.13)$ & - \\
\hline & $30-60 \mathrm{~cm}$ & $6.08(0.24)$ & $5.30(0.28)$ & - & $6.35(0.19)$ & $5.65(0.22)$ & $6.77(0.11)$ & $5.72(0.12)$ & - \\
\hline & $60-100 \mathrm{~cm}$ & $6.12(0.17)$ & $5.39(0.15)$ & - & $6.40(0.09)$ & $5.61(0.11)$ & 7.37 (n/a) & 6.15 (n/a) & - \\
\hline \multirow[t]{4}{*}{ Eroding (control) } & $0-10 \mathrm{~cm}$ & $5.99(0.18)$ & $5.33(0.20)$ & $1.24(0.05)$ & $6.09(0.06)$ & $5.46(0.05)$ & $6.79(0.14)$ & $5.91(0.18)$ & $1.13(0.04)$ \\
\hline & $10-30 \mathrm{~cm}$ & $5.85(0.22)$ & $5.03(0.23)$ & - & $5.87(0.06)$ & $5.21(0.06)$ & $6.77(0.17)$ & $5.57(0.17)$ & - \\
\hline & $30-60 \mathrm{~cm}$ & $5.37(0.14)$ & $4.88(0.17)$ & - & $5.59(0.11)$ & $4.98(0.03)$ & $6.40(0.21)$ & $5.23(0.27)$ & - \\
\hline & $60-100 \mathrm{~cm}$ & $5.86(0.11)$ & $5.10(0.16)$ & - & $5.97(0.09)$ & $5.17(0.08)$ & $6.65(0.12)$ & $5.72(0.24)$ & - \\
\hline
\end{tabular}

Standard error presented in parentheses $(n=7$ control, and $n=8$ burned).

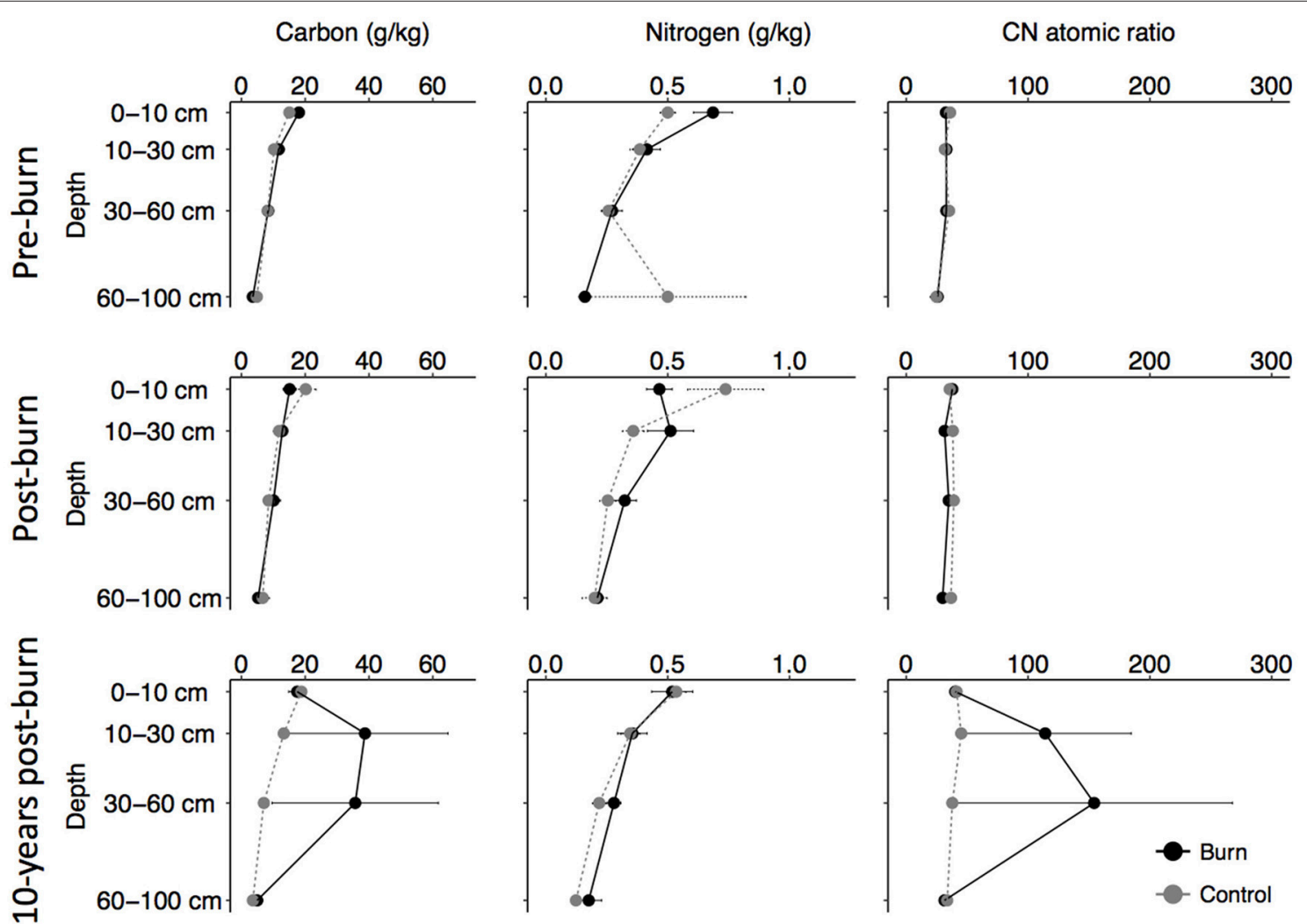

FIGURE 3 | Carbon $(\mathrm{C})$, nitrogen $(\mathrm{N})$, and the atomic C:N ratio in the eroding position before burn, 1 year post-fire, and 10-years post-fire. Error bars represent standard error. 
positions, when accounting for the effects of depth and time. The mean total $\mathrm{N}$ during the 2013 sampling period was $0.005 \mathrm{~g} / \mathrm{kg}$ and the mean total C was $18.7 \mathrm{~g} / \mathrm{kg}$ (Table 2).

\section{$\mathrm{SOC}$ in Fractions and PyC}

The concentrations of SOC fractions in the depositional landform position increased significantly between the pre-fire and 1-year post-fire sampling time points ( $p=0.00$, Figure 5). However, there was a significant decrease in the concentration of all three SOC fractions at the 10 -year post-fire sampling point ( $p=0.00)$ to below the pre-fire concentrations.

Linear mixed effects models indicated that the $C$ concentration in the organic carbon fractions from the eroding soils (Figure 6) significantly depended on sampling time, depths, and burn condition (Tables 3, 4). Concentrations of SOC fractions did not decline significantly with depth (PyC $p=0.82$, POC $p=0.94$, HOC $p=0.60$ ), but the top horizon had higher concentrations of each of the SOC fractions than the deeper horizons. The eroding soil regressions also indicated that

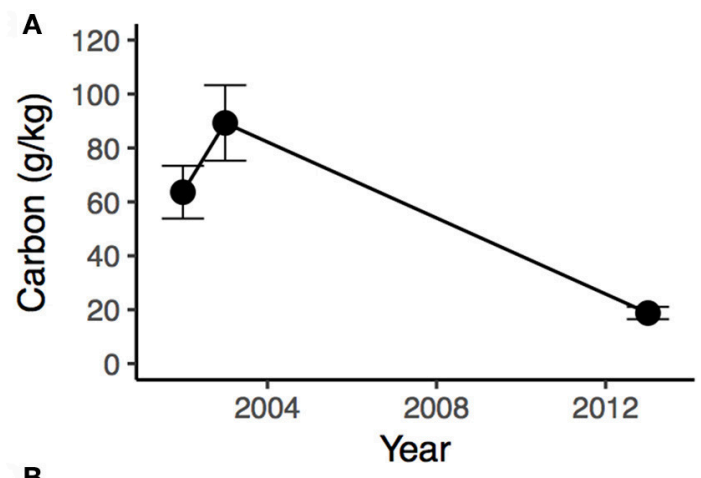

B

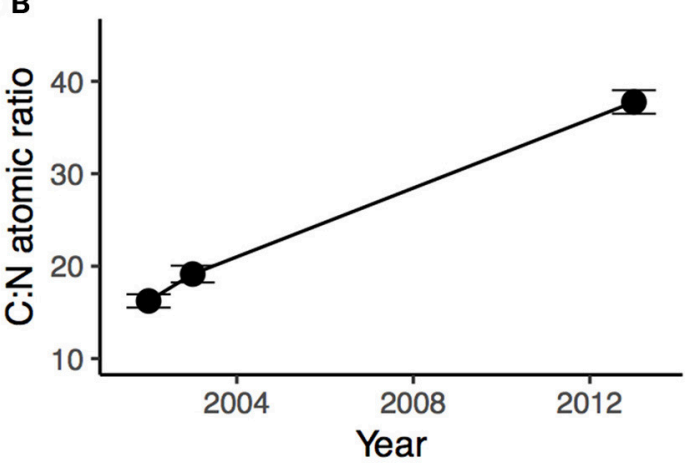

FIGURE 4 | Total C (A) and C:N ratio (B) for the depositional landform position for samples taken at 0-15 cm. Error bars represent standard error with $n=30$. the 2013 sampling time had significantly higher concentrations $(p=0.02)$ of each of the SOC fractions than was non-significantly (PyC $p=0.66$, POC $p=0.36$, HOC $p=0.18)$, more concentrated in burn plots compared with control plots, and was significantly ( $p=0.02$ ) more concentrated in 2013 compared with the earlier sampling points.

The statistical model of the SOC fractions in the surface soil indicated that there was no statistical difference between the preburn and 1 year post-fire sampling times, but that the 10 -year post-fire sampling had significantly lower SOC concentrations $(p=0.00)$, largely driven by the large decline in SOC fractions in the depositional landform positions. There were no significant differences in the burn and control plots on the eroding hillslope (PyC $p=0.92$, POC $p=0.79$, HOC $p=0.834$ ). Across the three SOC fractions and accounting for sampling time and burn, the eroding plots had significantly lower concentrations of the SOC fractions than the depositional landform positions (HOC $p=0.00$, POC $p=0.00)$, except for the PyC fraction $(p=0.05)$. However, the eroding landform position had significantly higher concentration of SOC fractions at the final sampling point than the depositional landform position.

In the eroding plots only model, the burned plots had nonsignificantly higher PyC concentrations than the unburned plots, and the 10-years post-fire sampling point had significantly higher concentrations of PyC compared with pre-burn $(p=0.00)$ and 1 -year post-burn $(p=0.02)$ concentrations. Both the burned and unburned plots had significantly higher HOC concentrations in the 10 -years post-fire sampling point compared with the preand post-fire sampling point $(p=0.00$ and $p=0.00)$. The unburned plots had slightly, but non-significantly $(p=0.64)$, lower concentrations of HOC than the burned plots.

In each of the sites, the three SOC fractions in the surface soils were summed and the proportion of $\mathrm{PyC}$ to total $\mathrm{C}$ was calculated (Figure 7, Tables 3, 4). There was no significant trend with ROC fraction with depth $(p=0.11)$ or between burn and control plot ( $p=0.44)$, but PyC made up a significantly higher proportion of hillslope SOC compared with the depositional landform position $(p=0.00)$. The PyC fraction was also significantly lower in the 10 -years post-fire time point compared with either of the first two time points $(p=0.00)$.

\section{Isotopic and Spectroscopic Composition of SOM}

For the 10 -year post fire eroding plots, $\delta^{13} \mathrm{C}$ values were significantly more positive $(p=0.02)$ in the control vs. burned plots (Figure 8). The $\delta^{13} \mathrm{C}$ of bulk SOM decreased with depth but the relationship was not statistically significant $(p=0.72)$. With increasing depth into the soil profiles of the eroding plots, the

TABLE 2 | Soil pH and bulk density for the depositional landform position, and summary elemental and stable isotope analyses for the depositional landform position soil collected in 2013.

\begin{tabular}{|c|c|c|c|c|c|c|c|c|}
\hline Depth & $\mathrm{pH}$ in $\mathrm{H}_{2} \mathrm{O}$ & $\mathrm{pH}$ in $\mathrm{CaCl}_{2}$ & Bulk density $\left(\mathrm{g} / \mathrm{cm}^{3}\right)$ & $\delta^{15} \mathrm{~N}$ & $\delta^{13} \mathrm{C}$ & C:N atomic ratio & Nitrogen $(\mathbf{g} / \mathbf{k g})$ & Carbon $(\mathrm{g} / \mathrm{kg})$ \\
\hline $0-15 \mathrm{~cm}$ & $6.85(0.12)$ & $5.80(0.14)$ & $1.22(0.12)$ & $3.84(0.18)$ & $-25.73(0.47)$ & $37.76(1.27)$ & 0.005 (0.000) & $18.7(2.2)$ \\
\hline
\end{tabular}

Standard error presented in parentheses $(n=30)$. 


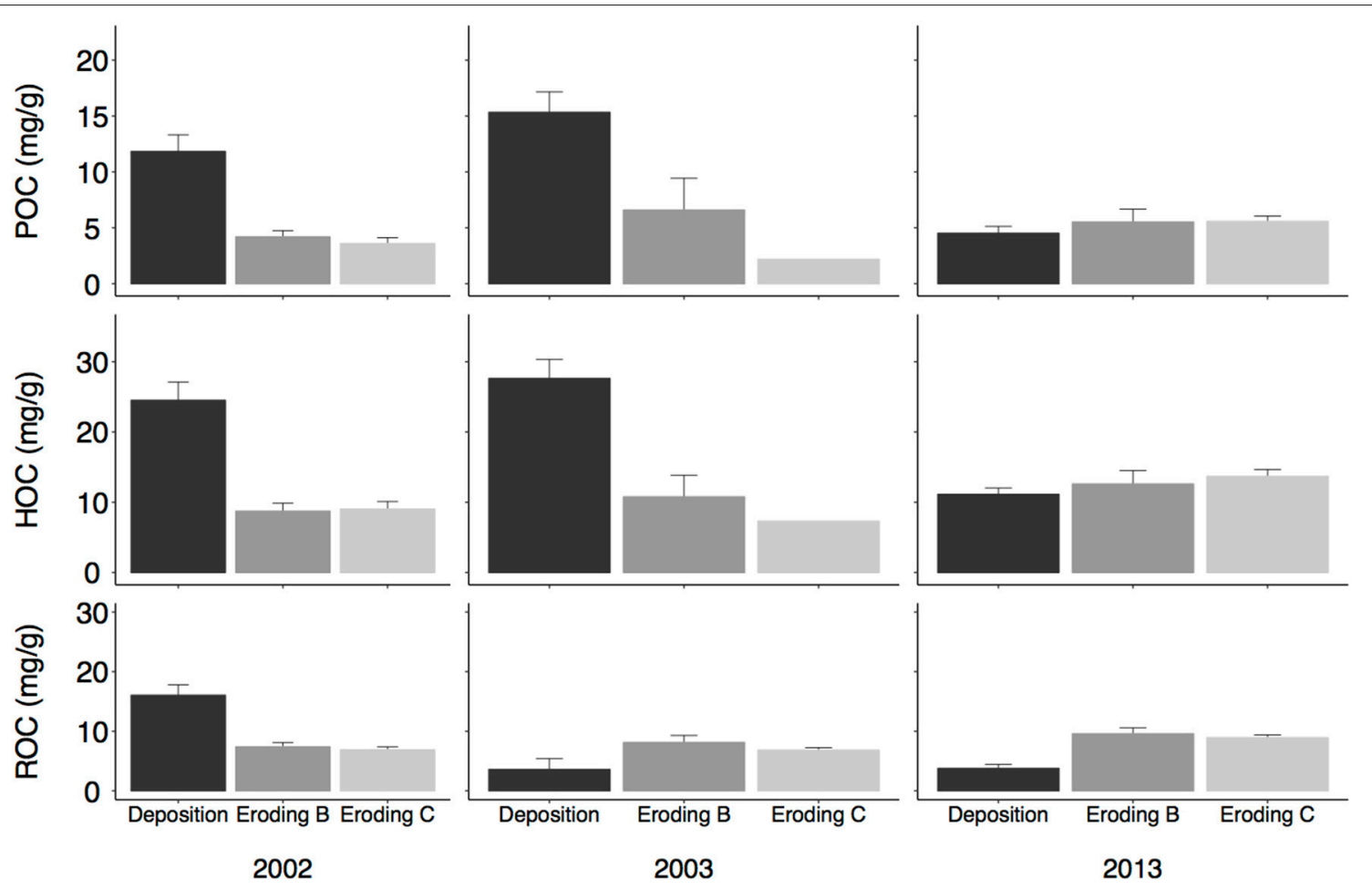

FIGURE 5 | Soil organic carbon fractions (particulate organic carbon, or POC; humic organic carbon, or HOC, and pyrogenic carbon, or ROC) from pre-fire (2002), 1 -year post-fire (2003), and 10-years post-fire (2013) surface soils. Eroding surface soils were collected from 0 to $10 \mathrm{~cm}$ and depositional soils were collected from 0 to $15 \mathrm{~cm}$. Error bars represent standard error with $n=16$ for eroding sites and $n=30$ for depositional sites. Eroding B refers to the burned eroding plots, and Eroding $\mathrm{C}$ refers to the control (unburned) eroding plots.

$\delta^{15} \mathrm{~N}$ values were significantly more positive in the control plots compared with the burned plots $(p=0.02)$.

The MIR data indicate that both the control and 10-year post-fire plots showed an increase in peak heights in the $-\mathrm{OH}$ function group $\left(3,700 \mathrm{~cm}^{-1}\right)$ with depth and a decrease in the $-\mathrm{CH}\left(2,940 \mathrm{~cm}^{-1}\right)$. The ester and phenol regions (1,159 and 995 $\mathrm{cm}^{-1}$ ) also showed a decrease in peak heights with depth into the soil profile in both the pre- and post-fire spectra based on DRIFT spectra designations of Araya et al. (2017). The most important differences in the MIR spectra in the soils from the burned and control plots, for regions of interest to SOM composition, (Figure 9) were observed in the spectral regions representing asymmetric and symmetric $\mathrm{C}-\mathrm{H}$ stretching vibrations in aliphatic compounds $\left(2,924\right.$ and $2,850 \mathrm{~cm}^{-1}$, respectively); $\mathrm{C}=\mathrm{C}$ stretching vibrations of aromatic compounds $\left(1,650 \mathrm{~cm}^{-1}\right) ; \mathrm{N}-\mathrm{H}$ bending vibrations and $\mathrm{C}=\mathrm{N}$ stretching vibrations in amides $\left(1,575 \mathrm{~cm}^{-1}\right)$; $\mathrm{C}-\mathrm{H}$ bending $\left(1,390,1,405\right.$, and $\left.1,470 \mathrm{~cm}^{-1}\right)$ in aliphatic groups; $\mathrm{C}-\mathrm{O}$ stretching and asymmetric stretching vibrations in carboxylic and phenolic groups $\left(1,270 \mathrm{~cm}^{-1}\right)$; and C-O symmetric vibrations in polysaccharides (1,080 and 1110 $\mathrm{cm}^{-1}$ ). The peak heights in the aromatic and polysaccharide regions were highest in the top soil $(0-10 \mathrm{~cm})$ of all landform positions and burned and control soils, due to higher $\mathrm{C}$ concentrations there. We also observed increased peak highest in the aromatic region at $10-30$ and $60-100 \mathrm{~cm}$ depths, and in the polysaccharide regions below $60 \mathrm{~cm}$ depths in the burned soils. All soil depths had increased peak heights in the amide region.

Comparing the pre-fire (2002) and post-fire (2003) NMR spectra of soil from the depositional position (Table 5, Figure 10) shows increased contribution of aryl and O-aryl groups (110165 ppm), alkyl (0-45 ppm), and ketones (190-215 ppm); and reduced contribution of $\mathrm{O}$ - and $\mathrm{N}$-substituted alkyls (45-110 ppm) and amide and carboxylic groups (165-190 ppm). The largest shift in distribution of $\mathrm{C}$ in the different organic functional groups was observed in the aryl region that saw an increase by $1.9 \%$ post-fire.

\section{DISCUSSION}

Following the Gondola fire, erosion redistributed soil C and $\mathrm{PyC}$ laterally down the hillslope. Overall, we found an increase in all SOC fractions in the depositional landform position 1-year postfire. By conservatively assuming the concentration of $\mathrm{C}$ and $\mathrm{PyC}$ in the transported sediment was equivalent to the concentration in post-fire control eroding plots, the initial mass movement of $380 \mathrm{Mg}$ of material (Carroll et al., 2007) equates to the transport of $7.6 \mathrm{Mg} \mathrm{C}$ and $2.4 \mathrm{Mg}$ PyC. When accounting for the 3.8 ha of source area, this is transport equates to $2.0 \mathrm{Mg} \mathrm{C}$ and $0.6 \mathrm{Mg} \mathrm{PyC}$ per ha. The post-fire transport contributed to the increase in the depositional soil C content from 63 to $89 \mathrm{~g} / \mathrm{kg} \mathrm{C}$, but by itself, did not contribute all the increase in soil C. It is likely that erosion 


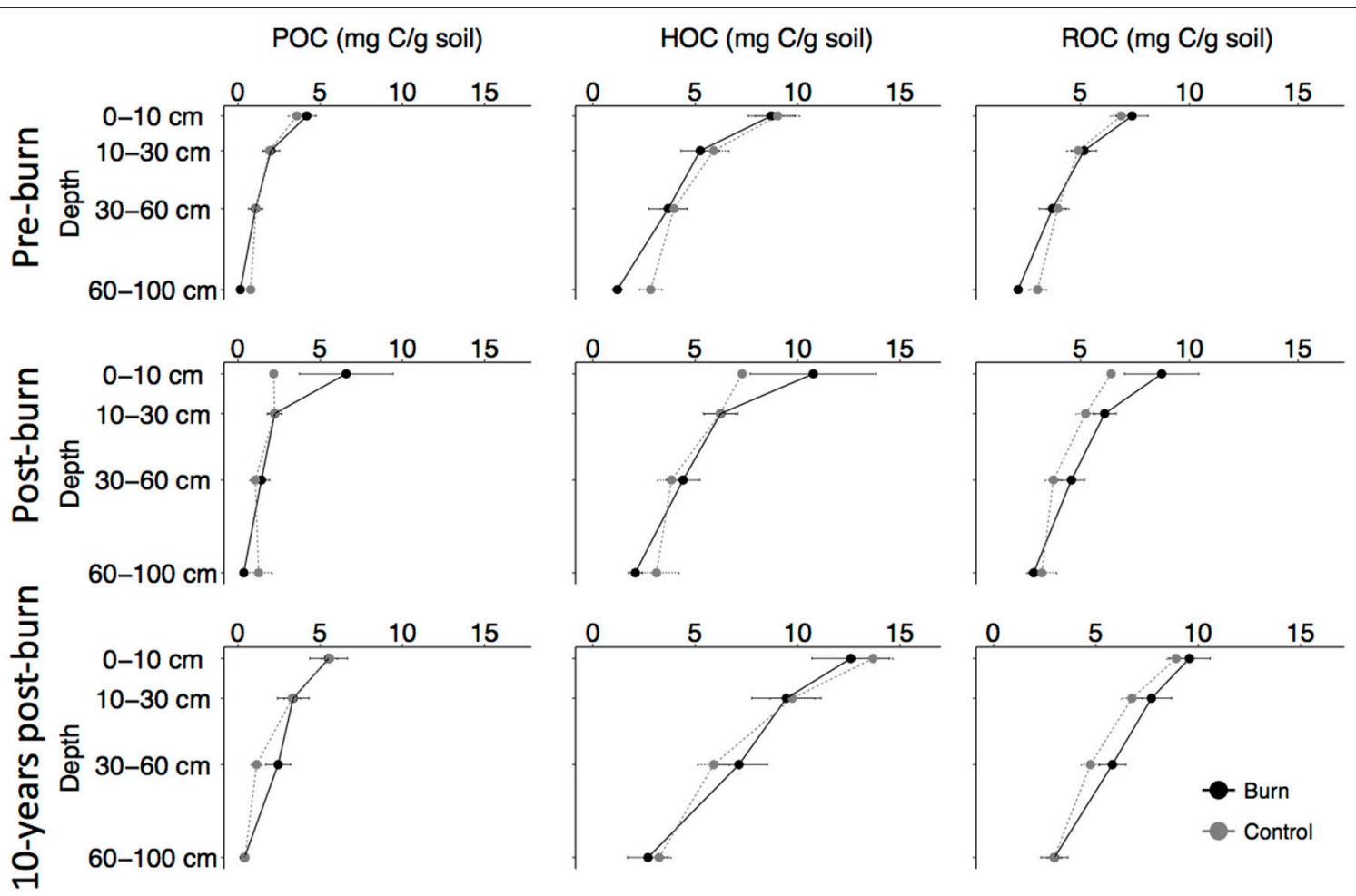

FIGURE 6 | Organic carbon fractions (particulate organic carbon, or POC; humic organic carbon, or HOC, and pyrogenic carbon, or ROC) for the eroding hillslope position from pre-fire, 1-year post-fire, and 10-years post-fire in burn and eroding plots. Error bars represent standard error with $n=8$, and where they are not visible the error is very small.

events from the remainder of the post-fire year preferentially transported SOC and $\mathrm{PyC}$ to this depositional landform position (Rumpel et al., 2006; Stacy et al., 2015). However, by 10-years post-fire, the SOC fractions in the depositional landform position sites declined to below pre-fire levels. This decline suggests either burial by subsequently eroded material with lower SOC levels or the rapid decomposition of SOC in that landform position. In the long-term, there were no significant changes in the carbon concentration of the top soil of the eroding plots, even after the major erosion event post-fire.

\section{Transport and Loss of Different SOC Fractions Due to Post-fire Erosion}

The slightly increased contribution of the PyC fraction in eroding hillslope plots that persisted even 10 years after the Gondola fire confirms the input of PyC from the fire (Figures 5, 6, 10). From our findings, the $\mathrm{PyC}$ continued to be lost from the eroding plots, presumably via ongoing erosion processes. Our data also show that $\mathrm{PyC}$ is a dynamic pool of SOC, as seen by the significant drop in the $\mathrm{PyC}$ fraction in the topsoil of the depositional landform position (Figure 5). These findings are consistent with previous work, where erosion was demonstrated to play a major role in lateral redistribution of $\mathrm{PyC}$ post-fire, with implications for persistence of PyC in dynamic landscapes (Rumpel et al., 2009, 2015).
All the SOC fractions in the depositional landform position increased in the 1-year post-fire sampling point and then decreased to below pre-fire concentrations at the 10-year sampling point. Based on our data, we conclude that this large initial increase is likely due to the mass-movement erosion event that deposited fire-altered material downhill after the fire. The subsequent loss of $\mathrm{C}$ in all the SOC fractions in the long-term suggests that this SOC material may not be stabilized if it remains on the surface of the depositional landform position. The depositional, riparian area characterized by higher concentrations of both $\mathrm{C}$ and $\mathrm{N}$, as well as wetter soil water conditions, could support higher decomposition rates. In comparison, the well-drained coarse soils in the eroding landform positions were relatively $\mathrm{C}$ - and $\mathrm{N}$-poor, but contained a higher proportion of the $\mathrm{PyC}$ as a fraction of total C (Figure 7). This finding is consistent with previous decomposition and other SOC studies that showed that rate of SOC loss through decomposition could be faster on the surface of OM rich and poorly drained depositional landform positions (Berhe, 2012, 2013). In addition to decomposition, SOC loss from the surface soil in the depositional landform position may become stabilized in the depositional landform positions particularly if it is buried by subsequently eroded material (Berhe et al., 2007; Doetterl et al., 2016).

The cycling and persistence of ROC or PyC, post-fire is controlled by numerous factors, including erosion and 
TABLE 3 | Eroding hillslope and surface soil model parameter estimates.

\begin{tabular}{|c|c|c|c|c|c|c|c|c|}
\hline & \multicolumn{4}{|c|}{ Eroding hillslope model } & \multicolumn{4}{|c|}{ Surface soil model } \\
\hline \multirow{4}{*}{ PyC } & Time & 0.10 & 0.02 & 4.46 & Time & -0.80 & 0.14 & -5.49 \\
\hline & Depth: $10-30 \mathrm{~cm}$ & -2.16 & 0.33 & -6.52 & Eroding hillslope & -3.74 & 1.95 & -1.91 \\
\hline & Depth: 30-60 cm & -3.73 & 0.33 & -11.26 & Control (unburned) & -0.25 & 2.82 & -0.09 \\
\hline & Control (unburned) & -0.92 & 0.69 & -1.32 & & & & \\
\hline \multirow[t]{4}{*}{ POC } & Intercept & -96.99 & 67.76 & -1.43 & Intercept & 1101.91 & 272.39 & 4.04 \\
\hline & Time & 0.05 & 0.03 & 1.51 & Time & -0.54 & 0.13 & -4.00 \\
\hline & Depth: 10-30 cm & -2.44 & 0.46 & -5.30 & Eroding hillslope & -4.96 & 1.80 & -2.75 \\
\hline & Depth: 30-60 cm & -3.57 & 0.46 & -7.74 & Control (unburned) & -0.66 & 2.60 & -0.25 \\
\hline \multirow{5}{*}{$\mathrm{HOC}$} & Time & 0.22 & 0.04 & 5.17 & Time & -0.84 & 0.21 & -3.97 \\
\hline & Depth: 10-30 cm & -3.59 & 0.59 & -6.08 & Eroding hillslope & -10.07 & 2.83 & -3.55 \\
\hline & Depth: 30-60 cm & -5.90 & 0.59 & -10.00 & Control (unburned) & 0.85 & 4.10 & 0.20 \\
\hline & Depth: 60-100 cm & -7.72 & 0.64 & -11.89 & & & & \\
\hline & Control (unburned) & -0.59 & 1.21 & -0.48 & & & & \\
\hline \multirow[t]{4}{*}{ PyC fraction } & Intercept & 7.39 & 1.90 & 3.88 & Intercept & 24.20 & 2.59 & 9.31 \\
\hline & Time & -0.00 & 0.00 & -3.68 & Time & -0.01 & 0.00 & -9.21 \\
\hline & Depth: $10-30 \mathrm{~cm}$ & 0.04 & 0.01 & 3.14 & Eroding hillslope & 0.11 & 0.01 & 6.65 \\
\hline & Depth: 30-60 cm & 0.08 & 0.01 & 6.40 & Control (unburned) & -0.02 & 0.02 & -0.93 \\
\hline
\end{tabular}

decomposition conditions (Bird et al., 2015). The PyC fraction in eroding positions increased slightly over time from pre-fire to 10 years after the Gondola Fire. This increase is likely due to the redistribution of material or further inputs of charred material. The Sierra Nevada is a highly fire-prone region (Westerling et al., 2006), and it might be that numerous fires in the Sierras after the Gondola Fire deposited ash and smoke in the vicinity (Peterson et al., 2015). The lack of significant difference in the PyC and other SOC fractions in the eroding burn and control plots also suggests input of PyC from sources other than the Gondola Fire itself, or that much of the PyC formed on the eroding hillslope was lost in the initial erosion event (Carroll et al., 2007) or via rapid decomposition (Kuzyakov et al., 2009; Nguyen et al., 2009). Reported decomposition rates for PyC range from decadal to millennial time scales (Kuzyakov et al., 2009; Lehmann et al., 2009; Bird et al., 2015), and reflect the source material for the PyC and environmental conditions. Reported rates of PyC breakdown can be orders of magnitude higher from controlled laboratory studies compared with field studies, but they suggest that under some conditions, microbial decomposition is responsible for the relatively rapid breakdown of PyC (Bird et al., 2015).

In the depositional landform position, undocumented further erosion events may have resulted in the loss of SOC fractions on the longer-term scale. At this site, erosion in the depositional landform position likely served as only a small loss for soil PyC, due to the lower slope in this landform position, no evidence for rill formation, which would drive elevated erosion, and the long-term preservation of this site from development. The initial eroded material contained a considerable concentration of ash (Carroll et al., 2007), which is highly susceptible to both wind and water erosion (Pereira et al., 2015). The mobilization of $1.5 \mathrm{Mg} \mathrm{C} / \mathrm{ha}$ and $0.7 \mathrm{Mg} \mathrm{PyC} / \mathrm{ha}$ in the initial erosion event was significant, however, the 1-year post-fire concentration of $\mathrm{PyC}$ in the depositional landform position is double that of the hillslope plots, suggesting that after the initial erosion event, more pyrogenic material was eroded and deposited there.

Topsoil material in depositional landform positions can become buried by subsequently eroded material, such that it is possible that the eroded SOC fractions that were initially eroded were buried by subsequent deposition of eroded material without higher levels of PyC-SOC (Berhe et al., 2007). These later erosion events generally transport more mineral material than the earlier erosion events, since pyrogenic material is typically preferentially transported in early erosion events after a fire (Rumpel et al., 2006, 2009; Yao et al., 2014). If the relatively SOCrich material that was originally deposited in the depositional landform position is buried with subsequent erosion, $\mathrm{PyC}$ and 
associated other soil $\mathrm{C}$ is likely to be physically stabilized in the soil profile of the depositional position.

The more negative $\delta^{13} \mathrm{C}$ in the surface soil of burned eroding sites at the 10-year post-fire sampling time point (Figure 8) suggests that there may have been preferential combustion of OM with more positive $\delta^{13} \mathrm{C}$, such as cellulose and hemicellulose in plant fragments, leaving behind more isotopically light material, such as lignin (Benner et al., 1987; Preston et al., 2006; Preston and Trofymow, 2015). For the $\delta^{15} \mathrm{~N}$ values, which are more negative post-fire, this observation is opposite to previously published work that demonstrated that soil $\delta^{15} \mathrm{~N}$ values increase with increasing charring temperature and time (Saito et al., 2007; Pyle et al., 2015). Nitrogen in soils is

TABLE 4 | Eroding hillslope and surface soil model comparisons with null model with maximum likelihood method.

\begin{tabular}{|c|c|c|c|c|c|}
\hline SOC fraction & $\chi^{2}$ & $d f$ & $p$ & AIC & BIC \\
\hline \multicolumn{6}{|c|}{ HILLSLOPE MODEL } \\
\hline PyC & 149.33 & 5 & 0.00 & 629.8 & 654.4 \\
\hline null model & & & & 769.2 & 778.4 \\
\hline POC & 73.18 & 5 & 0.00 & 722.7 & 747.3 \\
\hline null model & & & & 785.9 & 795.1 \\
\hline $\mathrm{HOC}$ & 130.48 & 5 & 0.00 & 812.8 & 837.4 \\
\hline null model & & & & 933.3 & 942.5 \\
\hline PyC fraction & 110.87 & 6 & 0.00 & -408.9 & -381.2 \\
\hline Null model & & & & -310.0 & -300.8 \\
\hline \multicolumn{6}{|c|}{ SURFACE SOIL MODEL } \\
\hline PyC & 34.30 & 3 & 0.00 & 1011.3 & 1029.0 \\
\hline null model & & & & 1039.6 & 1048.5 \\
\hline POC & 28.36 & 3 & 0.00 & 988.7 & 1006.4 \\
\hline null model & & & & 1011.1 & 1020.0 \\
\hline $\mathrm{HOC}$ & 32.50 & 3 & 0.00 & 1115.4 & 1133.0 \\
\hline null model & & & & 1141.9 & 1150.7 \\
\hline \multirow[t]{2}{*}{ PyC fraction } & 91.67 & 4 & 0.00 & -310.6 & -290.0 \\
\hline & & & & -226.9 & -218.1 \\
\hline
\end{tabular}

complex, and without further chemical description, difficult to interpret.

At the 10-years post-fire sampling point, the depositional landform position had relatively similar isotopic compositions to the eroding surface soil, $\delta^{15} \mathrm{~N}$ values of $2.44 \%$ o $( \pm 0.30 \%$ standard error, s.e.) and $3.84 \%$ o $( \pm 0.18 \%$ o s.e. $)$ and $\delta^{13} \mathrm{C}$ values of $-26.22 \%$ o $( \pm 0.34 \%$ s.e. $)$ and $-25.73 \%$ ( $\pm 0.47 \%$ s.e. $)$ for the burned eroding hillslope and depositional landform positions, respectively (Table 2 and Figure 8). This similarity is further evidence for the connection between surface soil and $\mathrm{OM}$ from the eroding positions and the soil within the depositional landform position. This long-term erosion may have led to the burial of earlier deposited material, which had much higher SOC concentration 1-year post-fire, such that what was sampled as top soil in the depositional landform position 10-years post-fire was mineral material that was more recently transported from the upslope eroding landform position.

It is likely that at least a fraction of the SOC fractions in the depositional landform position post-fire were lost via increased rates of decomposition (Berhe, 2012; Doetterl et al., 2012). The input of SOC and nutrients into the depositional landform position from the original mass flow event, along with the accumulation of water from precipitation and the nearby creek, could create ideal conditions for decomposition at this location compared with the eroding plots (Cheng et al., 2006; Johnson et al., 2007). The depositional landform position presents a range of conditions that can favor rapid loss of $\mathrm{PyC}$ that remains on the surface.

\section{Downwards Mobilization of SOC and SOM}

Leaching can also mobilize SOC downward in a soil profile, as evidenced by the small, but not significant, increase in HOC and $\mathrm{PyC}$ fractions at depth in the eroding landform positions at the final time point (Figure 6), along with a decrease in $\delta^{13} \mathrm{C}$ and $\delta^{15} \mathrm{~N}$ values throughout the burned eroding plots in the final sampling point (Figure 8). The HOC fraction may have also been more susceptible to leaching based on

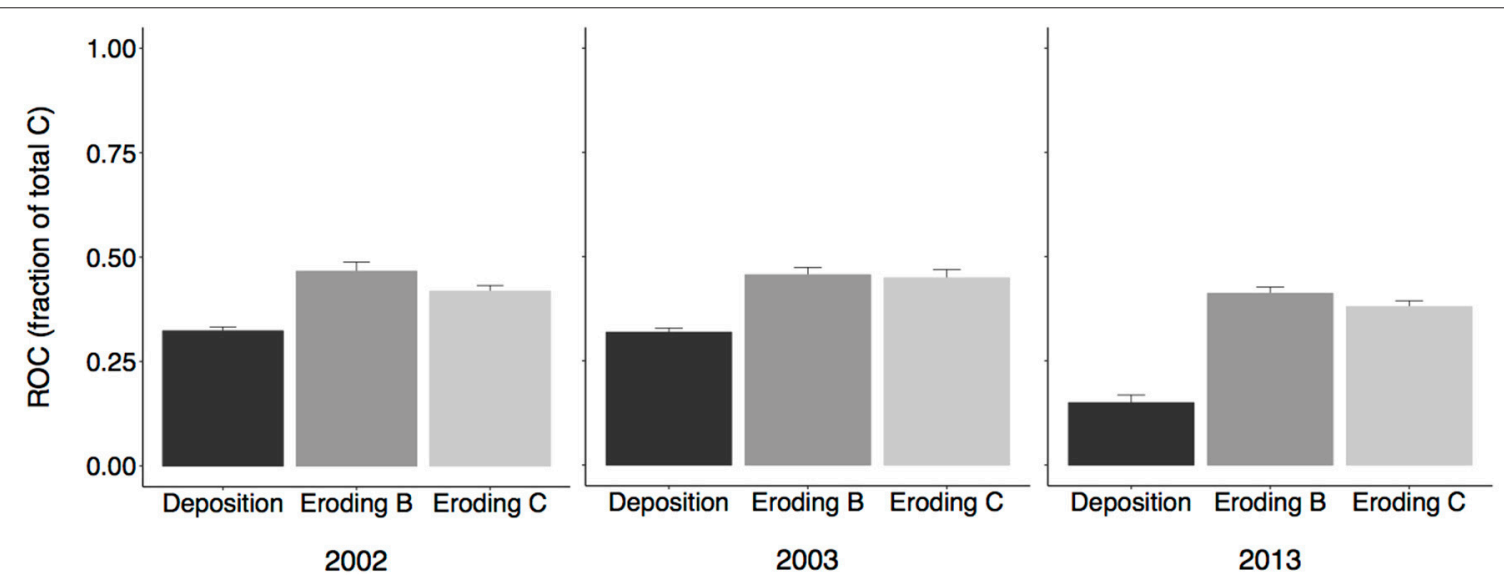

FIGURE 7 | Resistant organic carbon (ROC or PyC) as a fraction of total soil carbon in surface soils from burn and control plots. Eroding B refers to the burned eroding plots, and Eroding $\mathrm{C}$ refers to the control (unburned) eroding plots. Means are presented here for each sampling year with error bars representing standard error. 


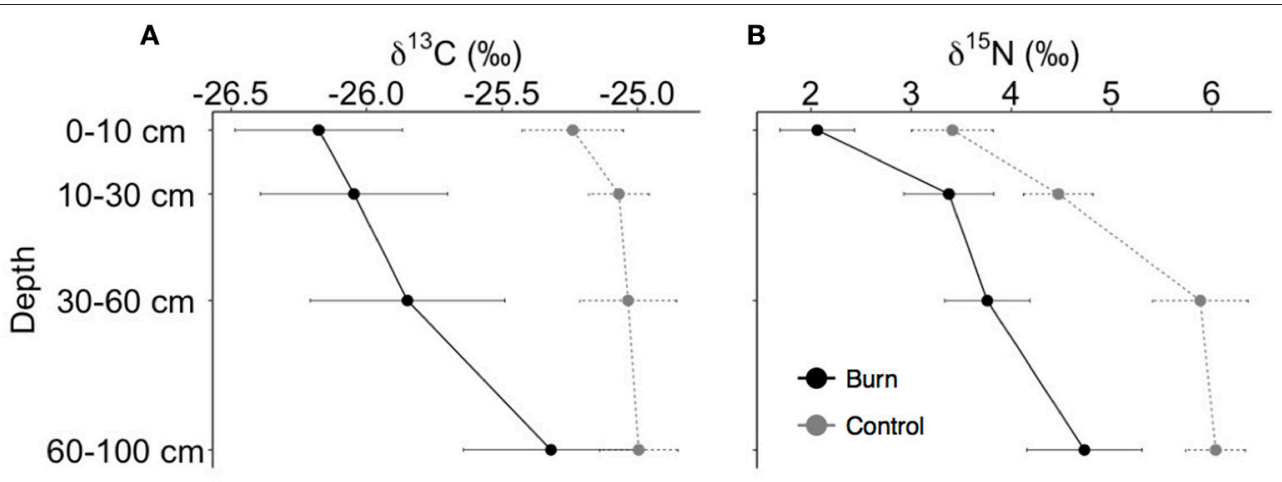

FIGURE 8 | Stable carbon (A) and nitrogen (B) isotopes for the eroding landform position 10 years post-fire. Error bars represent standard error.

its smaller size compared with POC. This HOC fraction may also serve as a more stable, deep soil C sink, as previous research has indicated that this smaller material is typically older than more particulate SOC constituents (Kleber et al., 2011).

The soils in the eroding positions of the Gondola fire site are coarse textured and porous, creating optimum conditions for vertical mobilization of bulk $\mathrm{C}, \mathrm{N}$, and $\mathrm{PyC}$ in dissolved and/or particulate form. The small shift in isotopic compositions of SOM suggests a shift in organic material and nutrients quality during post-fire recovery. The OM that is left behind may be more complex biomolecules, such as lignin that are more difficult to breakdown, or possibly more susceptible to leaching. Santos et al. (2016) previously showed that thermal alterations of topsoil can include leaching of dissolved $\mathrm{PyC}$ from soil, in particular after low and medium severity fire temperature regimes. It is possible though, in particular in soils with high clay content, the leaching process can be relatively slow. Major et al. (2010) found that in a year only $1 \%$ of their applied PyC was mobilized downward in the profile, and this change was not apparent in this study at the 1year post-fire sampling point. The leaching of $\mathrm{PyC}$ also depends on the particle size (dissolved vs. particulate form) and vegetation type. Slow leaching of PyC downward may be altered by the quality of PyC material left after the initial mass movement event and the post-fire vegetation recovery (Major et al., 2010; Kindler et al., 2011; Güereña et al., 2015). Leaching may be occurring in the depositional landform position, but we did not sample at depth into this landform position, as no pre-fire comparison samples exist for the deep soils in the depositional landform position.

\section{Implications of Post-fire Erosion for Long-Term Persistence of SOC and PyC}

Lateral redistribution of topsoil by soil erosion after wildfires has important implications for the dynamics of both bulk SOC and specific fractions. In the Gondola fire site, large amounts of $\mathrm{C}$ in all the SOC fractions were mobilized by a large erosion event immediately post-fire. However, we also found that significant amount of $\mathrm{C}$ from all the SOC fractions was lost from the surface depositional zone in the long term. It is clear from this 10 year,

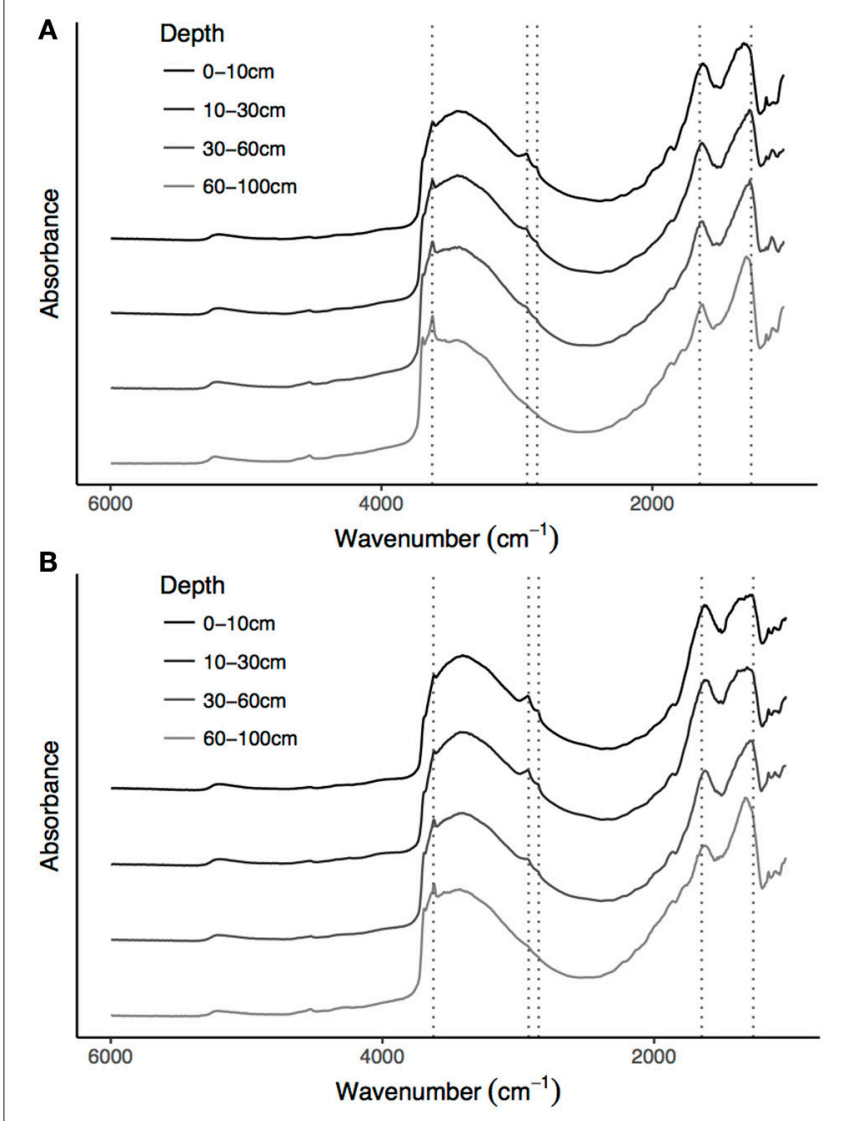

FIGURE 9 | Examples of MIR spectra of soil from a control (A) and burned (B) plot from the eroding position in the 10-year post-fire sampling time point. Shifts in peak intensities occurred at wavenumbers $1,270 \mathrm{~cm}^{-1}$ (carboxylic and phenolic groups), 1,650 cm $\mathrm{cm}^{-1}$ (aromatic compounds), 2,924 cm $\mathrm{cm}^{-1}$ (asymmetric C-H stretching), 2,850 $\mathrm{cm}^{-1}$ (symmetric C-H stretching), and $3,625 \mathrm{~cm}^{-1}$ (O-H bonding).

three sampling period study that $\mathrm{C}$ in all the SOC fractions in the eroding plots was considerably altered in the 10 -years post-fire. 
TABLE 5 | NMR functional group assignments of the depositional samples from before (2002) and after (2003) the Gondola Fire.

\begin{tabular}{|c|c|c|c|c|c|c|c|c|}
\hline $\begin{array}{l}\text { Sample } \\
\text { number }\end{array}$ & $\begin{array}{l}\text { Alkyl (0-45 } \\
\text { ppm) }\end{array}$ & $\begin{array}{l}\text { N-Alkyl/Methoxyl } \\
\text { (45-60 ppm) }\end{array}$ & $\begin{array}{c}\text { O-Alkyl } \\
(60-95 \mathrm{ppm})\end{array}$ & $\begin{array}{c}\text { Di-O-Alkyl } \\
\text { (95-110 ppm) }\end{array}$ & $\begin{array}{c}\text { Aryl (110-145 } \\
\text { ppm) }\end{array}$ & $\begin{array}{c}\text { O-Aryl } \\
\text { (145-165 ppm) }\end{array}$ & $\begin{array}{l}\text { Amide/Carboxyl } \\
\text { (165-190 ppm) }\end{array}$ & $\begin{array}{c}\text { Ketone } \\
(190-215 \text { ppm) }\end{array}$ \\
\hline \multicolumn{9}{|c|}{ PRE-FIRE DEPOSITION } \\
\hline 74 & 14.0 & 7.2 & 26.8 & 7.4 & 18.9 & 8.7 & 13.2 & 3.7 \\
\hline $90^{*}$ & 16.5 & 6.3 & 22.1 & 6.3 & 26.1 & 8.9 & 11.7 & 2.2 \\
\hline $114^{*}$ & 17.0 & 5.4 & 14.0 & 5.1 & 37.9 & 9.9 & 7.8 & 2.7 \\
\hline $67^{\star}$ & 16.2 & 7.4 & 25.2 & 7.3 & 20.2 & 8.7 & 11.9 & 3.0 \\
\hline 77 & 14.8 & 6.6 & 24.9 & 6.7 & 20.6 & 8.5 & 14.5 & 3.4 \\
\hline $85^{\star \dagger}$ & 18.9 & 7.5 & 25.6 & 6.9 & 18.7 & 7.0 & 12.9 & 2.5 \\
\hline $99^{*}$ & 13.5 & 6.3 & 16.1 & 5.3 & 32.8 & 12.1 & 10.6 & 3.3 \\
\hline $109^{*}$ & 14.1 & 6.4 & 21.0 & 7.7 & 23.5 & 11.6 & 11.6 & 4.1 \\
\hline 28 & 18.7 & 6.5 & 18.1 & 5.6 & 29.4 & 9.3 & 9.3 & 3.1 \\
\hline 32 & 15.7 & 6.6 & 20.8 & 6.5 & 25.4 & 9.8 & 11.9 & 3.4 \\
\hline 40 & 15.5 & 6.4 & 20.5 & 5.7 & 26.7 & 9.3 & 12.9 & 3.0 \\
\hline $48^{\star \dagger}$ & 13.3 & 5.7 & 14.8 & 5.5 & 34.8 & 12.5 & 10.2 & 3.3 \\
\hline 52 & 15.8 & 6.9 & 25.6 & 7.2 & 17.5 & 8.2 & 14.8 & 3.8 \\
\hline $64^{*}$ & 14.0 & 4.6 & 13.5 & 5.7 & 37.1 & 13.1 & 8.7 & 3.3 \\
\hline Mean & $15.9(0.6)$ & $6.2(0.2)$ & $19.9(1.5)$ & $6.1(0.2)$ & $27.2(2.5)$ & $10.0(0.7)$ & $11.4(0.9)$ & $3.3(0.1)$ \\
\hline
\end{tabular}

Samples analyzed with NMR were chosen using the Kennard-Stone algorithm to accurately include the variance within the dataset. Standard errors of mean functional group distributions are presented in parentheses. *indicates samples that were treated with HF prior to NMR analysis due to extremely poor signal acquisition. ${ }^{\dagger}$ indicates samples that have spectra plotted in Figure 10.

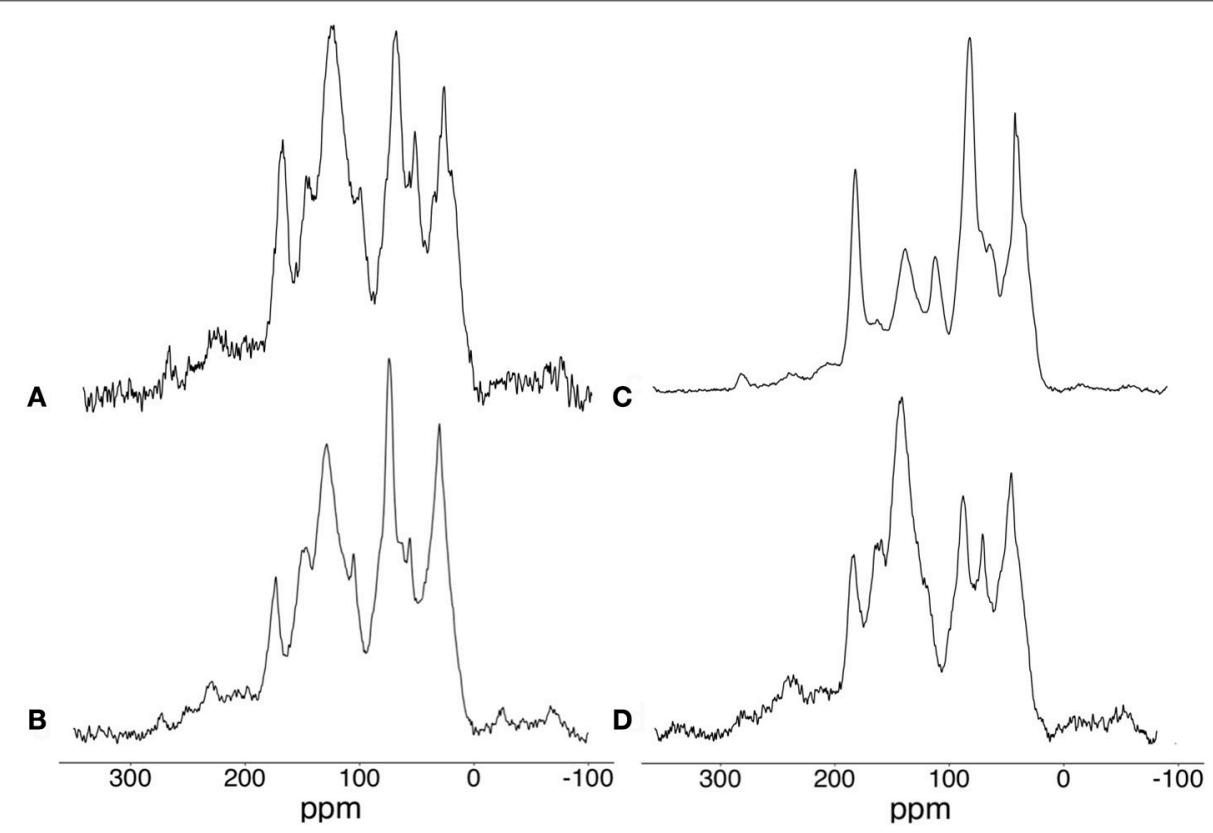

FIGURE 10 | Representative ${ }^{13} \mathrm{C}$ CPMAS NMR spectra of soil from pre-fire (A) and 10-year post-fire (B) samples from the depositional landform position that were not treated with HF, and pre-burn (C) and post-burn (D) samples that were treated with HF. 
This change in $\mathrm{C}$ in the different SOC fractions in the depositional landform position suggests some elevated biological processing of SOM in the long-term post-fire. The increase in the $\mathrm{PyC}$ fraction that we observed could be due to either erosion of $\mathrm{PyC}$ from upslope or from deposition of $\mathrm{PyC}$ in the form of ash or soot from nearby wildfires, such as the Rim Fire (Peterson et al., 2015). Vertical mobilization of $C$ in the different SOC fractions can lead to enhanced protection of both bulk $\mathrm{C}$ and $\mathrm{PyC}$ due to the decline in availability of oxygen and/or lower microbe biomass or active in deeper soil layers (Marin-Spiotta et al., 2014).

In contrast to the eroding landform positions, the depositional landform position lost significant proportions of $\mathrm{C}$ from all the SOC fractions over the 10 years likely due to combination of factors that includes ongoing transport and burial of top soil material from the eroding hillslope, leaching of $\mathrm{C}$ down the soil profile, and decomposition in situ. The long-term stability of SOC in depositional landform positions critically depends on the local decomposition conditions (Berhe, 2012) and erosion potential, as burial of SOC in depositional landform has also been demonstrated to be a stabilization mechanism for SOC and PyC (Berhe et al., 2007; Berhe and Kleber, 2013; Chaopricha and Marín-Spiotta, 2014).

While this study follows a single wildfire and its impacts on soil erosion, it highlights the roles that lateral and vertical redistribution of $\mathrm{C}$ post-fire can have implications for soil carbon dynamics. However, gaps remain in our understanding of the mechanisms through which erosional redistribution of PyC across fire-impacted landscapes can affect its stock and persistence in soil. So far, the relative rates of lateral and vertical transport of $\mathrm{PyC}$, with erosion, leaching, and bioturbation, across differing landscapes remains largely unknown (Güereña et al., 2015; Rumpel et al., 2015). The erosion of PyC is also significant, because this loss from eroding hillslopes post-fire, as illustrated after the Gondola fire, can lead to differences in its apparent environmental persistence based upon topographic features of a landscape. If eroded PyC is buried, it may act as an even more persistent $C$ sink. However, if eroded PyC is deposited into a landform position that has more favorable conditions for microbial breakdown, such as higher water content or higher nutrient availability, then the environmental persistence of $\mathrm{PyC}$ may be shorter. Considering that 1-5 Gt C is annually eroded (Stallard, 1998), and PyC makes up around 3\% of total soil C (Bird et al., 2015), erosion is responsible for the lateral transport of 3$5 \mathrm{Mt} \mathrm{PyC}$ annually. Hence, $\mathrm{PyC}$ transport is an important variable for accurately determining its mean residence time in the terrestrial ecosystem and its implications for soil carbon dynamics overall.

\section{CONCLUSIONS}

Our results show that erosion plays major roles in controlling stock, fluxes, and potentially stability and stabilization mechanisms of bulk $\mathrm{C}$ and $\mathrm{PyC}$ post-fire. After the Gondola fire, erosion changed the carbon sequestration trajectory of the system as over $1.5 \mathrm{Mg} \mathrm{PyC} / \mathrm{ha}$ and $0.7 \mathrm{Mg} \mathrm{C} / \mathrm{ha}$ of $\mathrm{C}$ in all SOC fractions was distributed away from the surface of the eroding landform positions, and deposited in the downhill riparian area. Ten years after the fire, soils at the depositional landform position had considerably lower concentrations of all SOC fractions, and retained proportionally lower concentrations of $\mathrm{PyC}$ than the eroding hillslope. We conclude that either the highly charred and SOC-rich material was buried in the depositional landform position with subsequent erosion events, or was more rapidly decomposed than in the eroding hillslope landform position.

The relatively low $\delta^{13} \mathrm{C}$ and $\delta^{15} \mathrm{~N}$ values in the burned soils suggests persistence of SOM with isotopically lower values, such as those from lignin, while other material with higher isotopic values, i.e., cellulose, was consumed either during combustion or via post-fire microbial processing. Better understanding of the long-term fate of $\mathrm{C}$ in dynamic landscapes post-fire is critical for constraining of terrestrial carbon budgets in a changing world.

\section{AUTHOR CONTRIBUTIONS}

$\mathrm{AB}$ conceived the study. RA, AB, and DJ designed the field sampling component of this research. DJ provided archived samples and data pertaining to them. JS contributed spectroscopic analyses of samples and statistical analysis of the spectral results. MF assisted with stable isotope analyses and interpretation. RA conducted majority of soil and statistical analyses, and was lead author of the manuscript. AB, DJ, JS, and MF contributed in writing of the manuscript and approve it for publication.

\section{FUNDING}

Funding for this work was provided from Hellman Family Foundation Grant and a National Science Foundation award (CAREER EAR-1352627) to AB and from UC Merced School of Natural Science to MF.

\section{ACKNOWLEDGMENTS}

We thank Emma McCorkle for her help in the field and lab, and Erin Carroll for help with archived data on the study site. We thank Bruce Hawke and Janine McGowan for performing FTIR and NMR spectroscopic analyses of soil samples at CSIRO in Adelaide, Australia, and David Araiza, Christina Bradley, Elizabeth Williams, and Bobby Nakamoto of the MF Stable Isotope lab at UC Merced for their assistance with the elemental and isotopic analyses. We also thank Stephen Hart for comments on earlier versions of this manuscript. 


\section{REFERENCES}

Abiven, S., Hengartner, P., Schneider, M. P. W., Singh, N., and Schmidt, M. W. I. (2011). Pyrogenic carbon soluble fraction is larger and more aromatic in aged charcoal than in fresh charcoal. Soil Biol. Biochem. 43, 1615-1617. doi: 10.1016/j.soilbio.2011.03.027

Ahmed, Z. U., Woodbury, P. B., Sanderman, J., Hawke, B., Jauss, V., Solomon, D., et al. (2017). Assessing soil carbon vulnerability in the Western USA by geospatial modeling of pyrogenic and particulate carbon stocks. J. Geophys. Res. Biogeosci. 122, 354-369. doi: 10.1002/2016JG003488

Araya, S., Meding, S., and Berhe, A. (2016). Thermal alteration of soil physicochemical properties: a systematic study to infer response of Sierra Nevada climosequence soils to forest fires. Soil 2, 351-366. doi: 10.5194/soil-2-35 1-2016

Araya, S. N., Fogel, M. L., and Berhe, A. A. (2017). Thermal alteration of soil organic matter properties: a systematic study to infer response of Sierra Nevada climosequence soils to forest fires. Soil 3, 31-44. doi: 10.5194/soil-3-31-2017

Baldock, J., Hawke, B., Sanderman, J., and Macdonald, L. (2013a). Predicting contents of carbon and its component fractions in Australian soils from diffuse reflectance mid-infrared spectra. Soil Res. 51, 577-595. doi: 10.1071/SR13077

Baldock, J., MacDonald, L., and Sanderman, J. (2013b). Foreword to 'Soil carbon in Australia's agricultural lands'. Soil Res. 51, i-ii. doi: 10.1071/SRv51n8_FO

Baldock, J., Sanderman, J., Macdonald, L., Puccini, A., Hawke, B., Szarvas, S., et al. (2014). Quantifying the allocation of soil organic carbon to biologically significant fractions. Soil Res. 51, 561-576. doi: 10.1071/SR12374

Battin, T., Luyssaert, S., Kaplan, L., Aufdenkampe, A., Richter, A., and Tranvik, L. (2009). The boundless carbon cycle. Nat. Geosci. 2, 598-600. doi: 10.1038/ngeo618

Benner, R., Fogel, M. L., Sprague, E. K., and Hodson, R. E. (1987). Depletion of ${ }^{13} \mathrm{C}$ in lignin and its implications for stable carbon isotope studies. Nature 329, 708-710. doi: 10.1038/329708a0

Berhe, A. A. (2012). Decomposition of organic substrates at eroding vs. depositional landform positions. Plant Soil 350, 261-280. doi: 10.1007/s11104-011-0902-z

Berhe, A. A. (2013). Effect of litterbags on rate of organic substrate decomposition along soil depth and geomorphic gradients. J. Soils Sediments 13, 629-640. doi: 10.1007/s11368-012-0639-1

Berhe, A. A., Harden, J. W., Torn, M. S., Kleber, M., Burton, S. D., and Harte, J. (2012). Persistence of soil organic matter in eroding versus depositional landform positions. J. Geophys. Res. Biogeosci. 117:G02019. doi: 10.1029/2011JG001790

Berhe, A. A., Harte, J., Harden, J. W., and Torn, M. S. (2007). The significance of erosion-induced terrestrial carbon sink. Bioscience 57, 337-346. doi: 10.1641/B570408

Berhe, A. A., and Kleber, M. (2013). Erosion, deposition, and the persistence of soil organic matter: mechanistic considerations and problems with terminology. Earth Surf. Process. Landforms 38, 908-912. doi: 10.1002/esp.3408

Bird, M. I., Wynn, J. G., Saiz, G., Wurster, C. M., and McBeath, A. (2015). The pyrogenic carbon cycle. Annu. Rev. Earth Planet. Sci. 43, 273-298. doi: 10.1146/annurev-earth-060614-105038

Boot, C., Haddix, M., Paustian, K., and Cotrufo, M. (2015). Distribution of black carbon in ponderosa pine forest floor and soils following the High Park wildfire. Biogeosciences 12, 3029-3039. doi: 10.5194/bg-12-3029-2015

Brewer, C. E., Chuang, V. J., Masiello, C. A., Gonnermann, H., Gao, X., Dugan, B., et al. (2014). New approaches to measuring biochar density and porosity. Biomass Bioenergy 66, 176-185. doi: 10.1016/j.biombioe.2014.03.059

Carroll, E. M., Miller, W. W., Johnson, D. W., Saito, L., Qualls, R. G., and Walker, R. F. (2007). Spatial analysis of a large magnitude erosion event following a Sierran Wildfire. J. Environ. Qual. 36, 1105-1105. doi: 10.2134/jeq2006.0466

Certini, G. (2005). Effects of fire on properties of forest soils: a review. Oecologia 143, 1-10. doi: 10.1007/s00442-004-1788-8

Chaopricha, N. T., and Marín-Spiotta, E. (2014). Soil burial contributes to deep soil organic carbon storage. Soil Biology Biochem. 69, 251-264. doi: 10.1016/j.soilbio.2013.11.011

Cheng, C., Lehmann, J., Thies, J., Burton, S., and Engelhard, M. (2006). Oxidation of black carbon by biotic and abiotic processes. Org. Geochem. 37, 1477-1488. doi: 10.1016/j.orggeochem.2006.06.022
DeBano, L. (2000). The role of fire and soil heating on water repellency in wildland environments: a review. J. Hydrol. 231, 195-206. doi: 10.1016/S0022-1694(00)00194-3

DeBano, L. F. (1991). "The effect of fire on soil properties," in Symposium on Management and Productivity of Westero-Montane Forest Soils, eds A. E. Harvey and L. F. Neuenschwander (Ogden, UT: USDA Forest Service, Intermountain Research Station).

Doetterl, S., Berhe, A. A., Nadeu, E., Wang, Z., Sommer, M., and Fiener, P. (2016). Erosion, deposition and soil carbon: a review of process-level controls, experimental tools and models to address $\mathrm{C}$ cycling in dynamic landscapes. Earth Sci. Rev. 154, 102-122. doi: 10.1016/j.earscirev.2015.12.005

Doetterl, S., Six, J., Van Wesemael, B., and Van Oost, K. (2012). Carbon cycling in eroding landscapes: geomorphic controls on soil organic C pool composition and C stabilization. Glob. Chang. Biol. 18, 2218-2232. doi: 10.1111/j.1365-2486.2012.02680.x

Eckmeier, E., Gerlach, R., Skjemstad, J., Ehrmann, O., and Schmidt, M. (2007) Minor changes in soil organic carbon and charcoal concentrations detected in a temperate deciduous forest a year after an experimental slash-and-burn. Biogeosciences 4, 377-383. doi: 10.5194/bg-4-377-2007

Giovannini, G., Lucchesi, S., and Giachetti, M. (1988). Effect of heating on some physical and chemical parameters related to soil aggregation and erodibility. Soil Sci. 146, 255-262. doi: 10.1097/00010694-198810000-00006

Gregorich, E., Greer, K., Anderson, D., and Liang, B. (1998). Carbon distribution and losses: erosion and deposition effects. Soil Tillage Res. 47, 291-302. doi: 10.1016/S0167-1987(98)00117-2

Güereña, D. T., Lehmann, J., Walter, T., Enders, A., Neufeldt, H., Odiwour, H., et al. (2015). Terrestrial pyrogenic carbon export to fluvial ecosystems: lessons learned from the White Nile watershed of East Africa. Glob. Biogeochem. Cycles 29, 1911-1928. doi: 10.1002/2015GB005095

Hammes, K., Torn, M. S., Lapenas, A. G., and Schmidt, M. W. I. (2008). Centennial black carbon turnover observed in a Russian steppe soil. Biogeosciences 5, 1339-1350. doi: 10.5194/bg-5-1339-2008

Harden, J. W., Sharpe, J. M., Parton, W. J., Ojima, D. S., Fries, T. L., Huntington, T. G., et al. (1999). Dynamic replacement and loss of soil carbon on eroding cropland. Glob. Biogeochem. Cycles 13, 885-901. doi: 10.1029/1999GB900061

Janik, L. J., Skjemstad, J. O., Shepherd, K. D., and Spouncer, L. R. (2007). The prediction of soil carbon fractions using mid-infrared-partial least square analysis. Aust. J. Soil Res. 45, 73-81. doi: 10.1071/SR06083

Jauss, V., Sullivan, P. J., Sanderman, J., Smith, D. B., and Lehmann, J. (2017). Pyrogenic carbon distribution in mineral topsoils of the northeastern United States. Geoderma 296, 69-78. doi: 10.1016/j.geoderma.2017.02.022

Johnson, D., Murphy, J., Walker, R., Glass, D., and Miller, W. (2007). Wildfire effects on forest carbon and nutrient budgets. Ecol. Eng. 31, 183-192. doi: 10.1016/j.ecoleng.2007.03.003

Johnson, D., Susfalk, R., Caldwell, T., Murphy, J., Miller, W., and Walker, R. (2004). Fire effects on carbon and nitrogen budgets in forests. Water Air Soil Pollut. Focus 4, 263-275. doi: 10.1023/B:WAFO.0000028359.17442.d1

Kennard, R. W., and Stone, L. A. (1969). Computer aided design of experiments. Technometrics 11, 137-148. doi: 10.1080/00401706.1969.10490666

Kindler, R., Siemens, J., Kaiser, K., Walmsley, D. C., Bernhofer, C., Buchmann, N., et al. (2011). Dissolved carbon leaching from soil is a crucial component of the net ecosystem carbon balance. Glob. Chang. Biol. 17, 1167-1185. doi: 10.1111/j.1365-2486.2010.02282.x

Kleber, M., Nico, P. S., Plante, A., Filley, T., Kramer, M., Swanston, C., et al. (2011). Old and stable soil organic matter is not necessarily chemically recalcitrant: implications for modeling concepts and temperature sensitivity. Glob. Chang. Biol. 17, 1097-1107. doi: 10.1111/j.1365-2486.2010.02278.x

Kuzyakov, Y., Subbotina, I., and Chen, H. (2009). Black carbon decomposition and incorporation into soil microbial biomass estimated by C labeling. Soil Biol. Biochem. 41, 210-219. doi: 10.1016/j.soilbio.2008.10.016

Lal, R. (2003a). Global potential of soil carbon sequestration to mitigate the greenhouse effect. CRC Crit. Rev. Plant Sci. 22, 151-184. doi: $10.1080 / 713610854$

Lal, R. (2003b). Soil erosion and the global carbon budget. Environ. Int. 29, 437-450. doi: 10.1016/S0160-4120(02)00192-7

Lal, R. (2004). Soil carbon sequestration impacts on global climate change and food security. Science 304, 1623-1627. doi: 10.1126/science.1097396 
Larsen, I., Macdonald, L., Brown, E., Rough, D., Welsh, M., Pietraszek, J., et al. (2009). Causes of post-fire runoff and erosion: water repellency, cover, or soil sealing? Soil Sci. Soc. Am. J. 73, 1393. doi: 10.2136/sssaj2007.0432

Lehmann, J., Czimczik, C., Laird, D., and Sohi, S. (2009). "Stability of biochar in soil," in Biochar for Environmental Management. Science and Technology, eds J. Lehmann and S. Joseph (Sterling, VA: Earthscan), 183-205.

Liang, B., Lehmann, J., Solomon, D., Kinyangi, J., Grossman, J., O’Neill, B., et al. (2006). Black carbon increases cation exchange capacity in soils. Soil Sci. Soc. Am. J. 70, 1719-1730. doi: 10.2136/sssaj2005.0383

Major, J., Lehmann, J., Rondon, M., and Goodale, C. (2010). Fate of soil-applied black carbon: downward migration, leaching and soil respiration. Glob. Chang. Biol. 16, 1366-1379. doi: 10.1111/j.1365-2486.2009.02044.x

Marin-Spiotta, E., Chaopricha, N. T., Plante, A. F., Diefendorf, A. F., Mueller, C. W., Grandy, A. S., et al. (2014). Long-term stabilization of deep soil carbon by fire and burial during early holocene climate change. Nat. Geosci. 7, 428-432. doi: $10.1038 /$ ngeo 2169

Masiello, C. (2004). New directions in black carbon organic geochemistry. Mar. Chem. 92, 201-213. doi: 10.1016/j.marchem.2004.06.043

Nguyen, B. T., Lehmann, J., Kinyangi, J., Smernik, R., Riha, S. J., and Engelhard, M. H. (2009). Long-term black carbon dynamics in cultivated soil. Biogeochemistry 92, 163-176. doi: 10.1007/s10533-008-9248-x

Pereira, P., Cerdà, A., Úbeda, X., Mataix-Solera, J., Arcenegui, V., and Zavala, L. (2015). Modelling the impacts of wildfire on ash thickness in a short-term period. Land Degradat. Dev. 26, 180-192. doi: 10.1002/ldr.2195

Peterson, D. A., Hyer, E. J., Campbell, J. R., Fromm, M. D., Hair, J. W., Butler, C. F., et al. (2015). The 2013 rim fire: implications for predicting extreme fire spread, pyroconvection, and smoke emissions. Bull. Am. Meteorol. Soc. 96, 229-247. doi: 10.1175/BAMS-D-14-00060.1

Pierson, F. B., Moffet, C. A., Williams, C. J., Hardegree, S. P., and Clark, P. E. (2009). Prescribed-fire effects on rill and interrill runoff and erosion in a mountainous sagebrush landscape. Earth Surf. Process. Landforms 34, 193-203. doi: 10.1002/esp.1703

Pierson, F. B., Williams, C. J., Hardegree, S. P., Clark, P. E., Kormos, P. R., and AlHamdan, O. Z. (2013). Hydrologic and erosion responses of sagebrush steppe following juniper encroachment, wildfire, and tree cutting. Rangeland Ecol. Manag. 66, 274-289. doi: 10.2111/REM-D-12-00104.1

Post, W. M., and Kwon, K. C. (2000). Soil carbon sequestration and land-use change: processes and potential. Glob. Chang. Biol. 6, 317-327. doi: 10.1046/j.1365-2486.2000.00308.x

Preston, C. M., Trofymow, J. A., and Flanagan, L. B. (2006). Decomposition, $\delta^{13}$ C, and the "lignin paradox". Can. J. Soil Sci. 86, 235-245. doi: 10.4141/S05-090

Preston, C. M., and Trofymow, J. A. (2015). The chemistry of some foliar litters and their sequential proximate analysis fractions. Biogeochemistry 126, 197-209. doi: 10.1007/s10533-015-0152-x

Pyle, L. A., Hockaday, W. C., Boutton, T., Zygourakis, K., Kinney, T. J., and Masiello, C. A. (2015). Chemical and isotopic thresholds in charring: implications for the interpretation of charcoal mass and isotopic data. Environ. Sci. Technol. 49, 14057-14064. doi: 10.1021/acs.est.5b03087

Renard, K. G., Foster, G. R., Weesies, G., McCool, D., and Yoder, D. (1997). Predicting Soil Erosion by Water: A Guide to Conservation Planning with the Revised Universal Soil Loss Equation (RUSLE). Washington, DC: US Government Printing Office.

Rumpel, C., Ba, A., Darboux, F., Chaplot, V., and Planchon, O. (2009). Erosion budget and process selectivity of black carbon at meter scale. Geoderma 154, 131-137. doi: 10.1016/j.geoderma.2009.10.006

Rumpel, C., Chaplot, V., Planchon, O., Bernadou, J., Valentin, C., and Mariotti, A. (2006). Preferential erosion of black carbon on steep slopes with slash and burn agriculture. CATENA 65, 30-40. doi: 10.1016/j.catena.2005.09.005

Rumpel, C., Leifeld, J., Santin, C., and Doerr, S. (2015). "Movement of biochar in the environment," in Biochar for Environmental Management: Science, Technology and Implementation 2nd Edn., eds J. Lehmann and S. Joseph (New York, NY: Routledge), 283-298.

Saito, L., Miller, W. W., Johnson, D. W., Qualls, R., Provencher, L., Carroll, E., et al. (2007). Fire effects on stable isotopes in a sierran forested watershed. J. Environ. Qual. 36, 91-100. doi: 10.2134/jeq2006.0233

Sanderman, J., Baldock, J., Hawke, B., Macdonald, L., Massis-Puccini, A., and Szarvas, S. (2011). National Soil Carbon Research Programme: Field and Laboratory Methodologies. Urrbrae, SA: CSIRO.

Sanderman, J., Farrell, M., Macreadie, P. I., Hayes, M., McGowan, J., and Baldock, J. (2017). Is demineralization with dilute hydrofluoric acid a viable method for isolating mineral stabilized soil organic matter? Geoderma 304, 4-11. doi: 10.1016/j.geoderma.2017.03.002

Santin, C., Doerr, S. H., Preston, C. M., and Gonzalez-Rodriguez, G. (2015). Pyrogenic organic matter production from wildfires: a missing sink in the global carbon cycle. Glob. Chang. Biol. 21, 1621-1633. doi: 10.1111/ gcb. 12800

Santos, F., Russell, D., and Berhe, A. A. (2016). Thermal alteration of water extractable organic matter in climosequence soils from the Sierra Nevada, California. J. Geophys. Res. Biogeosci. 121, 2877-2885. doi: 10.1002/2016JG003597

Scharlemann, J. P., Tanner, E. V., Hiederer, R., and Kapos, V. (2014). Global soil carbon: understanding and managing the largest terrestrial carbon pool. Carbon Manag. 5, 81-91. doi: 10.4155/cmt.13.77

Schmidt, M. W. I., Knicker, H., Hatcher, P. G., and Kogel-Knabner, I. (1997) Improvement of ${ }^{13} \mathrm{C}$ and ${ }^{15} \mathrm{~N}$ CPMAS NMR spectra of bulk soils, particle size fractions and organic material by treatment with $10 \%$ hydrofluoric acid. Eur. J. Soil Sci. 48, 319-328. doi: 10.1111/j.1365-2389.1997.tb00552.x

Shakesby, R., Coelho, C., Ferreira, A., Terry, J., and Walsh, R. (1993). Wildfire impacts on soil-erosion and hydrology in wet Mediterranean forest, Portugal. Int. J. Wildland Fire 3, 95-110. doi: 10.1071/WF9 930095

Shakesby, R., Doerr, S., and Walsh, R. (2000). The erosional impact of soil hydrophobicity: current problems and future research directions. J. Hydrol. 231, 178-191. doi: 10.1016/S0022-1694(00)00193-1

Skjemstad, J. O. (1994). The removal of magnetic materials from surface soils. Aust. J. Soil Res. 32, 1215-1229. doi: 10.1071/SR9941215

Skjemstad, J. O., Spouncer, L. R., Cowie, B., and Swift, R. S. (2004). Calibration of the Rothamsted organic carbon turnover model (RothC ver. 26.3) using measurable soil organic carbon pools. Aust. J. Soil Res. 42, 79-88. doi: $10.1071 /$ SR03013

Smernik, R. J., and Oades, J. M. (2000a). The use of spin counting for determining quantitation in solid state $13 \mathrm{C} \mathrm{NMR} \mathrm{spectra} \mathrm{of} \mathrm{natural} \mathrm{organic} \mathrm{matter:} 1$. Model systems and the effects of paramagnetic impurities. Geoderma 96, 101-129. doi: 10.1016/S0016-7061(00)00006-9

Smernik, R. J., and Oades, J. M. (2000b). The use of spin counting for determining quantitation in solid state 13C NMR spectra of natural organic matter. 2. HF-treated soil fractions. Geoderma 96, 159-171. doi: 10.1016/S0016-7061(00)00007-0

Smernik, R., and Oades, J. (2002). Paramagnetic effects on solid state carbon-13 nuclear magnetic resonance spectra of soil organic matter. J. Environ. Qual.31, 414-420. doi: 10.2134/jeq2002.4140

Soucémarianadin, L. N., Quideau, S. A., Wasylishen, R. E., and Munson, A. D. (2015). Early-season fires in boreal black spruce forests produce pyrogenic carbon with low intrinsic recalcitrance. Ecology 96, 1575-1585. doi: 10.1890/14-1196.1

Stacy, E., Hart, S. C., Hunsaker, C. T., Johnson, D. W., and Berhe, A. A. (2015). Soil carbon and nitrogen erosion in forested catchments: implications for erosioninduced terrestrial carbon sequestration. Biogeosci. Discuss. 12, 2491-2532. doi: 10.5194/bgd-12-2491-2015

Stallard, R. (1998). Terrestrial sedimentation and the carbon cycle: coupling weathering and erosion to carbon burial. Glob. Biogeochem. Cycles 12, 231-257. doi: 10.1029/98GB00741

Westerling, A. L., Hidalgo, H. G., Cayan, D. R., and Swetnam, T. W. (2006). Warming and earlier spring increase western US forest wildfire activity. Science 313, 940-943. doi: 10.1126/science.1128834

Yao, J., Hockaday, W. C., Murray, D. B., and White, J. D. (2014). Changes in firederived soil black carbon storage in a subhumid woodland. J. Geophys. Res. Biogeosci. 119, 1807-1819. doi: 10.1002/2014JG002619

Conflict of Interest Statement: The authors declare that the research was conducted in the absence of any commercial or financial relationships that could be construed as a potential conflict of interest.

Copyright (C) 2017 Abney, Sanderman, Johnson, Fogel and Berhe. This is an openaccess article distributed under the terms of the Creative Commons Attribution License (CC BY). The use, distribution or reproduction in other forums is permitted, provided the original author(s) or licensor are credited and that the original publication in this journal is cited, in accordance with accepted academic practice. No use, distribution or reproduction is permitted which does not comply with these terms. 